\title{
Bioarchaeological Analysis Mutual Relations of Populations Armenian Highlands and Eurasia Using Craniological and Dental Nonmetric Traits
}

\author{
Anahit Yu. Khudaverdyan ${ }^{1}$ \\ ${ }^{1}$ Institute of Archaeology and Ethnography National Academy of Science, Republic of Armenia \\ Correspondence: Anahit Khudaverdyan, Institute of Archaeology and Ethnography National Academy of \\ Science, Charents st.15, Yerevan 0025, Republic of Armenia. Tel: 374-565-884. E-mail: \\ ankhudaverdyan@gmail.com
}

Received: December 22, 2011 Accepted: February 7, 2012 Online Published: July 1, 2012

doi:10.5539/ach.v4n2p48

URL: http://dx.doi.org/10.5539/ach.v4n2p48

\begin{abstract}
Undertaken here is a multidimensional craniometric analysis of more than 254 ethnic groups of the Neolithic and Bronze Ages from the territory of Eurasia. On the basis of the received information, cluster analysis was done and has shown the genetic condensations of ethnoses and vectors of relatives or, conversely, distinctions between them. Craniometric and odontologic investigation of the Bronze Age is interesting and in connection with discussion about the origin of Indo-Europeans and about the place of their ancestral home. Different aspects of the problem of the ancestral home of Indo-Europeans are far from completely resolved and generate lively debate in the pages of scientific publications. New anthropological data allowed identification of alien Mediterranean characteristics influencing various ethnic Eurasian groups and revealed evidence of a migratory stream from the Armenian highlands and the Caucasus. This research provided new evidence of patterns of ethnic contact and intermixture in Western Eurasia.
\end{abstract}

Keywords: craniometrical characteristics, dental anthropology, biocultural, Mediterranean type, Bronze Ages, Armenian highlands

\section{Introduction}

The origin and development of ancient cultures is clearly connected with the general laws of social and economic development and environmental influence. The physical environment has played a significant role in all stages in the development of mankind, being a factor of paramount value favoring or constraining the cultural and economic progress of a society. In conjunction with the expansion of cattle-breeding and the emergence of ancient metallurgy, the Eurasian steppe, from serving as a factor dividing ethnic groups, became a factor uniting them in a larger community. The expansion into the steppes of wheeled vehicles invented in the Near East and "kibetka-houses" on wheels allowed cattlemen-farmers to move and survive with ease on the open steppes. Their movement across Eurasia in early times was not a military invasion, but a slow expansion caused by a decline in the child mortality rate and a resultant increase in population growth (Sarianidi, 2010). The wide expanse of the Eurasian steppes, offering favorable conditions for human life and the spread of information and technology, promoted a process of wide cultural integration in the Bronze Age throughout this area. The steppe was not only a conductor of new ideas and new people, but it also absorbed them, synthesizing and adapting to them new conditions. In what does the association consist? First of all, in a way of life that favored the strengthening of contacts between different groups that led to the occurrence of identical or very similar religious and ideological representations. A similar environment promoted the leveling of culture of the various ethnoses living in the steppe. Owing to similar circumstances, assimilation processes were facilitated that resulted in the contemporary ethnic diversity of the population of this territory, reflecting $\mathrm{s}$ it does a great variety of anthropological types. Reference to the morphological features of the ancient population of Eurasia was made in some previous works (Khudaverdyan, 2008, 2009, 2010, 2011a), which showed the participation of the indigenous population from the Near East, the Armenian highlands and Caucasus in the formation of the anthropological character of certain 
tribes and their movements, and also the desire to track the roots of the local substrate. The areas surrounding the Black Sea coast at certain stages of history became a center of interrelations of various cultures. Overland lines of contact existed between the Near East through the Armenian highlands and the Caucasus and on to the Balkans, and through Caucasus and the Balkans to the north Black Sea coast and in the return direction. The ethnic history of the region developed under the interaction of various groups since the early Bronze Age, among which the Indo-European played a leading role, those tribes having created one of the most advanced cultures of the then-contemporary world. The purpose of this paper is to compare craniometric and odontologic variations among Neolithic and Bronze Age inhabitants of Armenian highlands, Caucasus, Iran, with Neolithic and Bronze Age samples from the European-Russo-Kazakh steppe, south Central Asia, and Siberia. All we can do with ancient skeletal material is determine cases of population movements, and then decide if any such movements match the relevant period of Indo-European expansions and the relevant lands penetrated by Indo-Europeans.

\subsection{Indo-European Origins}

The most popular current theory places the Indo-European homeland in steppes of Eastern Europe. The hypothesis about a West European ancestral home of Indo-European also enjoys popularity (Merpert, 1974; Klejn, 1990, 2010; Mallory 1997 et al.). This theory was most comprehensively proposed by the Russian linguist and historian D'iakonov (1985). D'iakonov makes an extensive survey of the linguistic and archaeological evidence and determines that the Proto-Indo-Europeans had a mixed economy based on farming and animal husbandry. D'iakonov demonstrates that the Balkan-Carpathian region has all the features known for Proto-Indo-European culture. D'iakonov (1999) explained that the Indo-Europeans managed to expand because of their comparative advantage over the more primitive societies that surrounded them. The reason was that the population speaking the Indo-European proto-language changed to a diet of milk and meat, and had a sufficiently developed agriculture (growing barley, wheat, grapes and vegetables). The surrounding population which lived in the Early Primitive Phase, and thus was by far not so numerous, adopted the agricultural achievements of the Indo-Europeans, and at the same time also adopted their language; thus the further movements involved not only the original Indo-Europeans but also tribes who had adopted the language and the mores, the latter including the Primitive Communal stage customs which the Indo-Europeans had evolved. Finnish scholar Wiik (2003) has also proposed Indo-European origins in Southeast Europe ( $<$ http://www.lib.helsinki.fi/bff/399/wiik.html $>$ ).

Others connect the ancestral home of these groups with the Armenian highlands, Transcaucasia and Northern Mesopotamia (Gamkrelidze \& Ivanov, 1981, 1984, 1990; Renfrew, 1987; Safronov, 1989; Gray \& Atkinson, 2003; Ivanov, 2010, etc.). The Armenian highlands hypothesis is also favored by Renfrew's (1987) Neolithic Discontinuity Theory; this proposes a dispersal of Proto-Indo-Europeans originating in Neolithic Armenian highlands. C. Renfrew's original hypothesis suggested that the speakers of the Proto-Indo-European language lived in Anatolian highlands during the Neolithic era, and it linked the distribution of the historical Indo-European languages to the geographical expansion of the Neolithic revolution during the VII and VI millennia BC. This view arose directly from the "farming dispersal" hypothesis, since farming came to Europe from the Anatolian highlands. C. Renfrew (1998) has somewhat modified his previous theory of an Anatolian origin of the Indo-Europeans. Now, he thinks that Proto-Indo-European unity originated on the northern edge of the Balkans (Southeast Europe), in agreement with the opinion of D'iakonov. Kuzmina (2008) has this view.

According to Gamkrelidze and Ivanov (1981), the way north from the outskirts of the Iranian plateau in Central and Central East Asia was well-known by the agriculture and cattle breeding tribes. These may have included carriers and speakers of future Kelto-Italian, Illyria, German, Balto-Slavic speech. The latter, settling across Central Asia in territories to the east of the Caspian Sea (and having also entered into contact with the ancestors of the Siberian people), then turned to the west and by the III millennium BC occupied areas from the Volga steppes to the Northern Black coast; later, already from the middle of the III millennium BC, their advancement further to the west, north, and southwest began. Khlopina's opinion (1970) believes an Iranization of the northern steppes from the south of Central Asia took place in the late III to the II millennium BC. According to Khlopin, this process was accompanied by a transition in the specified steppe territories to a more productive economy, the first spreading of skills such as cattle breeding, agriculture, metallurgy, etc., Sarianidi (1998a,b, 2010) also is a supporter of the hypothesis of Gamkrelidze and Ivanov. He specifies that the migration of the founders of the Bactria and Margiani cultures were from the Near East.

The purpose of this paper is to compare craniometric and odontologic variation among Neolithic and Bronze Age inhabitants of Armenian highlands, Caucasus, Iran, with Neolithic and Bronze Age samples from the European-Russo-Kazakh steppe, south Central Asia, and Siberia, in order to test which of the hypotheses best explain the origins and subsequent interactions in the steppes of migrating Bronze Age inhabitants from the Armenian highlands. 


\section{Materials and Methods}

In total, the analysis included 223 craniological series from the territory of Eurasia (Table 1). The paper does not allow us to provide a long list of the analyzed groups and references and the links to sources from which they have been generated. For sources of data about the majority of groups, see Schwidetzky and Rösing (1990), Khudaverdyan (2009). Ten cranial variables of those defined by Martin (1928) provide the metrical basis for the current study (numbers of variables as defined by Martin (1928): basic diameters of a cranium: length (1), breadth (8), height (17), minimal width of a forehead /9/, bizygomatric breadth /45/, upper facial height /48/, orbital breadth (51), orbital height (52), nasal breadth (54), nasal height (55)). These were analyzed using canonical variates analisis and Mahalanobis $\mathrm{D}^{2}$ generalized distances between each pair of samples adjusted for number (Rightmire, 1969). They were analyzed in 3 steps in order to maximize the number of skeletal samples included in the study.

Table 1. Eurasian craniological samples

\begin{tabular}{|c|c|c|c|}
\hline & Site (s) & Sample name & Date \\
\hline 1 & Armenian highland & Landjik (Kura-Araks culture) & c. $4000-3000 \mathrm{BC}$ \\
\hline 2 & Armenian highland & Djarat & c. $4000-3000 \mathrm{BC}$ \\
\hline 3 & Armenian highland & Shengavit & c. $4000-3000 \mathrm{BC}$ \\
\hline 4 & Armenian highland & Total group (Kura-Araks culture) & c. $4000-3000 \mathrm{BC}$ \\
\hline 5 & Armenian highland & Artik & c. XV/XIV BC \\
\hline 6 & Armenian highland & Nerkin Getashen & c. XV/XIV BC \\
\hline 7 & Armenian highland & Total group: Artik, Nerkin Getashen & c. XV/XIV BC \\
\hline 8 & Armenian highland & Noraduz & c. XI-IX/ VIII BC \\
\hline 9 & Armenian highland & Saryxan & c. XI-IX/ VIII BC \\
\hline 10 & Armenian highland & Arcvakar & c. XI-IX/ VIII BC \\
\hline 11 & Armenian highland & Camakaberd & c. XI-IX/ VIII BC \\
\hline 12 & Armenian highland & Orom & c. XI-IX/ VIII BC \\
\hline 13 & Armenian highland & $\begin{array}{c}\text { Total group: Noraduz, Saryxan, Arcvakar, } \\
\text { Camakaberd }\end{array}$ & c. XI-IX/ VIII BC \\
\hline 14 & Georgia & Total group (Kura-Araks culture) & c. $4000-3000 \mathrm{BC}$ \\
\hline 15 & Georgia & Tkviavi & c. $4000-3000 \mathrm{BC}$ \\
\hline 16 & Georgia & Kiketi & c. $4000-3000 \mathrm{BC}$ \\
\hline 17 & Georgia & Total group (Late Bronze Age - I period) & c. XI-IX/ VIII BC \\
\hline 18 & Georgia & Total group (Late Bronze Age - II period) & c. XI-IX/VIII BC \\
\hline 19 & Georgia & Samtavro (Late Bronze Age - I period) & c. XI-IX/ VIII BC \\
\hline 20 & Georgia & Samtavro (Late Bronze Age - II period) & c. XI-IX/ VIII BC \\
\hline 21 & Georgia & Tserovani (Late Bronze Age - I period) & c. XI-IX/ VIII BC \\
\hline 22 & Georgia & Samtavro & c. Õ-VI BC \\
\hline 23 & Western Azerbaijan & Mingechayr & c. Õ-VIII BC \\
\hline 24 & Western Azerbaijan & Mingechayr & c. VII - V BC \\
\hline 25 & Anatolia & Catal Huyuk & c. $6000-5000 \mathrm{BC}$ \\
\hline 26 & Iran & El-Ubeida & $4000 \mathrm{BC}$ \\
\hline 27 & Iran & Alisar Huyuk & c. $3000-1000 \mathrm{BC}$ \\
\hline 28 & Iran & Ikiztepe & c. $2600-2200 \mathrm{BC}$ \\
\hline 29 & Iran & Caratash & c. $4000-3000 \mathrm{BC}$ \\
\hline 30 & Iran & Tepe Gissar II & c. $4000-3000 \mathrm{BC}$ \\
\hline
\end{tabular}




\begin{tabular}{|c|c|c|c|}
\hline 31 & Iran & Tepe Gissar III & $3000 \mathrm{BC}$ \\
\hline 32 & Iran & Ras-Shamra & c. $3000-2000 \mathrm{BC}$ \\
\hline 33 & Iran & Minet-E-Beida & $2000 \mathrm{BC}$ \\
\hline 34 & Iran & Tepe-Djemshidi & c. $2500-2000 \mathrm{BC}$ \\
\hline 35 & Iran & Shar-i-Sotra & c. $2900-2000 \mathrm{BC}$ \\
\hline 36 & Iran & Kish & c. $2900-2800 \mathrm{BC}$ \\
\hline 37 & Pakistan & Saraikhola & c. $2000-1000 \mathrm{BC}$ \\
\hline 38 & Pakistan & Timargarkha & c. $2000-1000 \mathrm{BC}$ \\
\hline 39 & India & $\mathrm{R}-37$ & c. $3000-1000 \mathrm{BC}$ \\
\hline 40 & India & Kharappa, R-37 & c. $4000-3000 \mathrm{BC}$ \\
\hline 41 & Jericho & Total group & c. $3300-3100 \mathrm{BC}$ \\
\hline 42 & Egypt & Badari & c. $4000-3500 \mathrm{BC}$ \\
\hline 43 & Egypt & Naqada & c. $4000-3000 \mathrm{BC}$ \\
\hline 44 & Egypt & Acmant & c. $4000-3000 \mathrm{BC}$ \\
\hline 45 & Egypt & Sakkara I & c. $2925-2790 \mathrm{BC}$ \\
\hline 46 & Egypt & Abydos I & c. $2925-2790 \mathrm{BC}$ \\
\hline 47 & Egypt & Heluan & c. $2925-2790 \mathrm{BC}$ \\
\hline 48 & Egypt & Sakkara II & c. $2925-2790 \mathrm{BC}$ \\
\hline 49 & Egypt & El Khozan & c. $2655-2155 \mathrm{BC}$ \\
\hline 50 & Egypt & Sakkara III & c. $2750-2450 \mathrm{BC}$ \\
\hline 51 & Egypt & Nada ed-Der II & c. $2290-1785 \mathrm{BC}$ \\
\hline 52 & Egypt & El-Kubanieh Sud & c. $2450-1785 \mathrm{BC}$ \\
\hline 53 & Egypt & El-Kubanieh Nord & c. $2134-1785 \mathrm{BC}$ \\
\hline 54 & Egypt & Sedment & c. $2134-1991 \mathrm{BC}$ \\
\hline 55 & Egypt & Drah Aboul Neggah & c. $2134-1991 \mathrm{BC}$ \\
\hline 56 & Egypt & Theben I & c. $2134-1991 \mathrm{BC}$ \\
\hline 57 & Egypt & Qubbet el Hawa & c. $2290-1550 \mathrm{BC}$ \\
\hline 58 & Egypt & Elephantine & c. $2450-1650 \mathrm{BC}$ \\
\hline 59 & Egypt & Unternubien A-Gruppe & c. $2925-2635 \mathrm{BC}$ \\
\hline 60 & Turkmenia & Total group (Namazga culture) & c. $4000-3000 \mathrm{BC}$ \\
\hline 61 & Central Asia & Tumek-Kichidjic & c. $4000-3000 \mathrm{BC}$ \\
\hline 62 & Central Asia & Karatepe & c. $4000-3000 \mathrm{BC}$ \\
\hline 63 & Central Asia & Geoksur & c. $4000-3000 \mathrm{BC}$ \\
\hline 64 & Central Asia & Kapuztepe & c. $4000-3000 \mathrm{BC}$ \\
\hline 65 & Central Asia & Altyn-Depe & c. $4000-3000 \mathrm{BC}$ \\
\hline 66 & Central Asia & Parhai & $3000 \mathrm{BC}$ \\
\hline 67 & Central Asia & Dzarkytan & c. $2000-1000 \mathrm{BC}$ \\
\hline 68 & Central Asia & Sapallitepe & c. $2000-1000 \mathrm{BC}$ \\
\hline 69 & Central Asia & Ranni Tylkhar & c. $2000-1000 \mathrm{BC}$ \\
\hline 70 & Central Asia & Tigrovaya Balka & c. $2000-1000 \mathrm{BC}$ \\
\hline 71 & Central Asia & Makonimor & c. $2000-1000 \mathrm{BC}$ \\
\hline 72 & Central Asia & Symbar & c. $2000-1000 \mathrm{BC}$ \\
\hline 73 & Central Asia & Kokcha 3 & c. $2000-1000 \mathrm{BC}$ \\
\hline
\end{tabular}




\begin{tabular}{|c|c|c|c|}
\hline 74 & Northeast Kazakhstan & Total group (Andronovo culture) & c. $1700-1200 \mathrm{BC}$ \\
\hline 75 & Western Kazakhstan & Total group (Andronovo culture) & c. $1700-1200 \mathrm{BC}$ \\
\hline 76 & Northern Caucasus & Total group & c. $4600-3000 \mathrm{BC}$ \\
\hline 77 & Northern Caucasus & Total group & c. $2000-1000 \mathrm{BC}$ \\
\hline 78 & Northern Caucasus & Total group & (Kobanskaya culture) \\
\hline 79 & Daghestan & Ginchi & c. $4000-3000 \mathrm{BC}$ \\
\hline 80 & Ossetia & Tliski & (Kobanskaya culture) \\
\hline 81 & Kalmykia & Total group (Pit Grave-Catacomb time) & c. $3000 \mathrm{BC}$ \\
\hline 82 & Kalmykia & Evdik I & c. $4000-3000 \mathrm{BC}$ \\
\hline 83 & Kalmykia & Total group (Catacomb culture) & c. $3000-2000 \mathrm{BC}$ \\
\hline 84 & Kalmykia & Elista-Arxara (Catacomb culture) & c. $3000-2000 \mathrm{BC}$ \\
\hline 85 & Kalmykia & Chokhrai I and II (Catacomb culture) & c. $3000-2000 \mathrm{BC}$ \\
\hline 86 & Volga region & Krivaya lyka (Pit Grave culture) & c. $4000-3000 \mathrm{BC}$ \\
\hline 87 & Volga region & Krivaya lyka (Pit Grave-Catacomb time) & $3000 \mathrm{BC}$ \\
\hline 88 & Volga region & Krivaya lyka (Timber Grave culture) & c. $1800-1100 \mathrm{BC}$ \\
\hline 89 & Volgo-Uralja & Total group (Khvalynsk culture) & c. $4000-3000 \mathrm{BC}$ \\
\hline 90 & Volgo-Uralja & Total group (Pit Grave culture) & c. $4000-3000 \mathrm{BC}$ \\
\hline 91 & Volgo-Uralja & Total group (Poltavka culture) & $3000 \mathrm{BC}$ \\
\hline 92 & Volgo-Uralja & Total group (Potapovsky culture) & $3000 \mathrm{BC}$ \\
\hline 93 & Ural & Mellitamak & c. $5000-4000 \mathrm{BC}$ \\
\hline 94 & Ciscaucasia and Volga region & Total group (Lolinsky /Post Catacomb/) & c. $2500-1800 \mathrm{BC}$ \\
\hline 95 & Ciscaucasia and Volga region 7 & Total group (Krivoluksky /Post Catacomb/) & c. $2500-1800 \mathrm{BC}$ \\
\hline 96 & Saratov region & Total group (Timber Grave culture) & c. $1800-1100 \mathrm{BC}$ \\
\hline 97 & Volgo-Astrakhan region & Total group (Timber Grave culture) & c. $1800-1100 \mathrm{BC}$ \\
\hline 98 & Forest-steppe the Volga region & Total group (Timber Grave culture) & c. $1800-1100 \mathrm{BC}$ \\
\hline 99 & Volgo-Uralja & Spiridonovka II-Roszestveno I & c. $2000-1500 \mathrm{BC}$ \\
\hline 100 & Volgo-Uralja & Spiridonovka II & c. $2000-1500 \mathrm{BC}$ \\
\hline 101 & Volgo-Uralja & Roszestveno I & c. $2000-1500 \mathrm{BC}$ \\
\hline 102 & Volgo-Uralja & Xrichovka et al. & c. $1800-1100 \mathrm{BC}$ \\
\hline 103 & Volgo-Uralja & Pure Jr I & c. $1800-1100 \mathrm{BC}$ \\
\hline 104 & Volgo-Uralja & Studenci & c. $1800-1100 \mathrm{BC}$ \\
\hline 105 & Volgo-Uralja & Novoselki & c. $1800-1100 \mathrm{BC}$ \\
\hline 106 & Volgo-Uralja & Syezzhe & c. $1800-1100 \mathrm{BC}$ \\
\hline 107 & Volgo-Uralja & Alekseevski & c. $1800-1100 \mathrm{BC}$ \\
\hline 108 & Volgo-Uralja & N.Orlianka I & c. $1800-1100 \mathrm{BC}$ \\
\hline 109 & Volgo-Uralja & Poplavskoe & c. $1800-1100 \mathrm{BC}$ \\
\hline 110 & Volgo-Uralja & Xrichovka & c. $1800-1100 \mathrm{BC}$ \\
\hline 111 & Volgo-Uralja & Luzanovka & c. $1800-1100 \mathrm{BC}$ \\
\hline 112 & Volgo-Uralja & Uranbash & c. $1800-1100 \mathrm{BC}$ \\
\hline 113 & Volga region & Total group (Abashevskaya culture) & c. $2500 \mathrm{BC}$ \\
\hline 114 & Volga region & Total group (Fatianovo culture) & c. $2000-1500 \mathrm{BC}$ \\
\hline 115 & Volga region & Total group (Early Fatianovo) & c. $2000-1700 \mathrm{BC}$ \\
\hline 116 & Volga region & Total group (Late Fatianovo) & c. $1700-1500 \mathrm{BC}$ \\
\hline
\end{tabular}




\begin{tabular}{|c|c|c|c|}
\hline 117 & Bashkiria & Total group (Timber Grave culture) & c. $1800-1100 \mathrm{BC}$ \\
\hline 118 & Bashkiria & $\begin{array}{c}\text { (Old-Jabalaklinsky /Timber Grave } \\
\text { culture /) }\end{array}$ & c. $1800-1100 \mathrm{BC}$ \\
\hline 119 & Bashkiria & Total group (Timber Grave culture) & c. $1800-1100 \mathrm{BC}$ \\
\hline 120 & Altai & Total group (culture Afanasevo) & c. $4000-2000 \mathrm{BC}$ \\
\hline 121 & Altai & Total group (culture Karakolskaya) & c. XVIII-XVI BC \\
\hline 122 & Altai & Total group (culture Eluninskaya) & c. XX-XVII BC \\
\hline 123 & Altai & Total group (culture Andronovo) & c. $1700-1200 \mathrm{BC}$ \\
\hline 124 & Russian plain & Lovci & c. $4000-3000 \mathrm{BC}$ \\
\hline 125 & Russian plain & Chernaya gora & $3000 \mathrm{BC}$ \\
\hline 126 & Don region & Pavlovski & $2000 \mathrm{BC}$ \\
\hline 127 & Don region & Jiasirev (Timber Grave culture) & c. $1800-1100 \mathrm{BC}$ \\
\hline 128 & Don region & Elizavetovski & c. VI - IIIBC \\
\hline 129 & Don region & Beglica & c. VI - IIIBC \\
\hline 130 & Don region & Nomads of steppe barrows I & c. IX - VIIBC \\
\hline 131 & Don region & Nomads of steppe barrows II & c. VI - IIIBC \\
\hline 132 & Dnieper region & Total group (Pit Grave cultures) & c. $4000-3000 \mathrm{BC}$ \\
\hline 133 & Dnieper region & Total group (Catacomb culture) & c. $3000-2000 \mathrm{BC}$ \\
\hline 134 & Dnieper region & Total group (Mnogovalikovaya culture) & c. $1800-1500 \mathrm{BC}$ \\
\hline 135 & Left bank of Dnepr & Total group (Timber Grave culture) & c. $1800-1100 \mathrm{BC}$ \\
\hline 136 & Right bank of Dnepr & Total group (Timber Grave culture) & c. $1800-1100 \mathrm{BC}$ \\
\hline 137 & Crimea & Total group (the Kemi Oba culture) & c. $3500-2000 \mathrm{BC}$ \\
\hline 138 & Steppe Crimea & Total group (Timber Grave culture) & c. $1800-1100 \mathrm{BC}$ \\
\hline 139 & Ukraine & Total group (Pit Grave cultures) & c. $4000-3000 \mathrm{BC}$ \\
\hline 140 & Ukraine & Total group (Catacomb culture) & c. $3000-2000 \mathrm{BC}$ \\
\hline 141 & Ukraine & Total group (Cucuteni- Trypillian culture) & c. $4000-3000 \mathrm{BC}$ \\
\hline 142 & Ukraine & Total group (Timber Grave culture) & c. $1800-1100 \mathrm{BC}$ \\
\hline 143 & Ukraine & $\begin{array}{c}\text { Total group (Timber Grave culture, flat } \\
\text { burials) }\end{array}$ & c. $1800-1100 \mathrm{BC}$ \\
\hline 144 & Ukraine & Shirochanski & c. $1800-1100 \mathrm{BC}$ \\
\hline 145 & Ukraine & $\begin{array}{c}\text { Chernyanka and Wide (Timber Grave } \\
\text { culture /belozer phase/) }\end{array}$ & c. $1800-1100 \mathrm{BC}$ \\
\hline 146 & Moldova & Sarkovka I (Mariupolskaya culture) & c. $4000-4500 \mathrm{BC}$ \\
\hline 147 & Moldova & Vikhvatintsi (Cucuteni- Trypillian culture) & c. $4000-3000 \mathrm{BC}$ \\
\hline 148 & Moldova & Total group (Cucuteni- Trypillian culture) & c. $4000-3000 \mathrm{BC}$ \\
\hline 149 & Moldova & Kalfa & c. XV - XIII BC \\
\hline 150 & Moldova & Old Bedrazji (culture Hoya) & c. $1400-1200 \mathrm{BC}$ \\
\hline 151 & Dnestr region & Ostrovec (culture Hoya) & c. $1400-1200 \mathrm{BC}$ \\
\hline 152 & Latvia & Kreichi & c. $2000 \mathrm{BC}$ \\
\hline 153 & Latvia & Kiwytkalnsk (Corded Ware culture) & c. $2000 \mathrm{BC}$ \\
\hline 154 & Poland & Total group (Linear Pottery culture) & c. $5500-4000 \mathrm{BC}$ \\
\hline 155 & Germany & Total group (Linear Pottery culture) & c. $5500-4000 \mathrm{BC}$ \\
\hline 156 & Austria & Total group (Linear Pottery culture) & c. $5500-4000 \mathrm{BC}$ \\
\hline
\end{tabular}




\begin{tabular}{|c|c|c|c|}
\hline 157 & Romania & $\begin{array}{l}\text { Bilche-Zlota (Cucuteni- Trypillian } \\
\text { culture) }\end{array}$ & c. $4000-3000 \mathrm{BC}$ \\
\hline 158 & Romania & Dridu-Russe (Gumelnița culture) & c. $4000-3000 \mathrm{BC}$ \\
\hline 159 & Romania & Total group (burials with ochre) & c. $4500-3500 \mathrm{BC}$ \\
\hline 160 & East Romania & Total group (burials with ochre) & c. $4500-3500 \mathrm{BC}$ \\
\hline 161 & Romania & Balintesh (culture Monteoru) & c. VI-VIII BC \\
\hline 162 & Romania & Trushesht (culture Hoya) & c. $1400-1200 \mathrm{BC}$ \\
\hline 163 & Romania & Oktegrebe & c. $2500-1800 \mathrm{BC}$ \\
\hline 164 & Poland & Total group (Globular Amphora Culture) & c. $3400-2800 \mathrm{BC}$ \\
\hline 165 & Poland & Total group I (Corded Ware culture) & c. $3200-2300 \mathrm{BC}$ \\
\hline 166 & Poland & Total group II (Corded Ware culture) & c. $2500-2000 \mathrm{BC}$ \\
\hline 167 & Poland & Total group III (Corded Ware culture) & c. $3200-2300 \mathrm{BC}$ \\
\hline 168 & Poland & Brjest-Kuyvski (Corded Ware culture) & c. $3200-2300 \mathrm{BC}$ \\
\hline 169 & Poland & Total group (culture Zlota) & c. $2400-1800 \mathrm{BC}$ \\
\hline 170 & Slovakia & Total group I (Corded Ware culture) & c. $3200-2300 \mathrm{BC}$ \\
\hline 171 & Western Europe & Rass & c. $3000 \mathrm{BC}$ \\
\hline 172 & Greece & Total group (Neolith) & c. $4000-3000 \mathrm{BC}$ \\
\hline 173 & Greece & Total group & c. $3000-1400 \mathrm{BC}$ \\
\hline 174 & Western Europe & Total group (culture Reisen) & c. $4000-3500 \mathrm{BC}$ \\
\hline 175 & Western Europe & Total group (culture Michelsberger) & c. $3500-3000 \mathrm{BC}$ \\
\hline 176 & Western Europe & Total group (culture Lengyel) & c. $3500-2500 \mathrm{BC}$ \\
\hline 177 & Western Europe & Total group (culture Vinca) & c. $3500-2500 \mathrm{BC}$ \\
\hline 178 & Western Europe & Total group (Globular Amphora Culture) & c. $3400-2800 \mathrm{BC}$ \\
\hline 179 & Czechia & Bogemia (Corded Ware culture) & c. $3200-2300 \mathrm{BC}$ \\
\hline 180 & Czechia & Bogemia(Globular Amphora Culture) & c. $3400-2800 \mathrm{BC}$ \\
\hline 181 & Czechia & Total group (Corded Ware culture) & c. $3200-2300 \mathrm{BC}$ \\
\hline 182 & Hungary & Alshonemedia (Corded Ware culture) & c. $3200-2300 \mathrm{BC}$ \\
\hline 183 & Sicily & Total group & c. $2000 \mathrm{BC}$ \\
\hline 184 & Germany & Total group (culture Baden) & c. $2500-2000 \mathrm{BC}$ \\
\hline 185 & Western Europe & Ponte San Pietro, Rinaldone & c. $2500-2000 \mathrm{BC}$ \\
\hline 186 & Western Europe & Arene Candide & c. $3200-2500 \mathrm{BC}$ \\
\hline 187 & Sicily & Isnello & c. $2500-1800 \mathrm{BC}$ \\
\hline 188 & Sardinia & Total group & c. $2500-2000 \mathrm{BC}$ \\
\hline 189 & Switzerland & Total group (culture Cortaillod) & c. $3000-2500 \mathrm{BC}$ \\
\hline 190 & France & SOM Grottes de la Meuse & c. $2500-2000 \mathrm{BC}$ \\
\hline 191 & Languedoc & Chalk & c. $2500-1800 \mathrm{BC}$ \\
\hline 192 & France & Grands Causses Lozere & c. $3000-2000 \mathrm{BC}$ \\
\hline 193 & France & Causses d`Aveyron & c. $2500-1800 \mathrm{BC}$ \\
\hline 194 & Germany & Steinkisten, Hessen & c. $2500-1800 \mathrm{BC}$ \\
\hline 195 & Germany & Altendorf, Steinkiste & c. $2500-1800 \mathrm{BC}$ \\
\hline 196 & Germany & Mecklenburg & c. $3000-2500 \mathrm{BC}$ \\
\hline 197 & Germany & Total group (culture Walternienb.) & c. $2600-2400 \mathrm{BC}$ \\
\hline 198 & Germany & Total group (Corded Ware culture) & c. $2500-2000 \mathrm{BC}$ \\
\hline
\end{tabular}




\begin{tabular}{|c|c|c|c|}
\hline 199 & Western Europe & Zimnicea & c. $2000-1000 \mathrm{BC}$ \\
\hline 200 & Western Europe & Lika Gospie & c. $1600-1400 \mathrm{BC}$ \\
\hline 201 & Western Europe & Lerna & c. $2000-1600 \mathrm{BC}$ \\
\hline 202 & Western Europe & Kerameikos, submyk. & c. $1200-1000 \mathrm{BC}$ \\
\hline 203 & Crete & Total group & c. $2000-1100 \mathrm{BC}$ \\
\hline 204 & Western Europe & Mokrin & c. $1800-1500 \mathrm{BC}$ \\
\hline 205 & Hungary & Tape & c. $1800-1100 \mathrm{BC}$ \\
\hline 206 & Western Europe & Total group (culture Aunjetitz I) & c. $1800-1500 \mathrm{BC}$ \\
\hline 207 & Western Europe & Mahren(culture Aunjetitz II) & c. $1800-1500 \mathrm{BC}$ \\
\hline 208 & Western Europe & Bajc (culture Hurbanovo) & c. $1800-1500 \mathrm{BC}$ \\
\hline 209 & Czechia & Total group (culture Knovizer) & c. $1800-1000 \mathrm{BC}$ \\
\hline 210 & Poland & Total group (culture Mierzanowice) & c. $2100-1700 \mathrm{BC}$ \\
\hline 211 & Silesia & Total group I & c. $1800-1500 \mathrm{BC}$ \\
\hline 212 & Silesia & Total group II & c. $1800-1500 \mathrm{BC}$ \\
\hline 213 & Western Europe & Gemeinlebarn & c. $1800-1500 \mathrm{BC}$ \\
\hline 214 & Hamburg & Total group & c. $1800-1500 \mathrm{BC}$ \\
\hline 215 & Western Europe & Großbrembach, Aunj & c. $1800-1500 \mathrm{BC}$ \\
\hline 216 & Western Europe & Nahermemmingen & c. $1800-1600 \mathrm{BC}$ \\
\hline 217 & Western Europe & Lozere BZ & c. $1800-1500 \mathrm{BC}$ \\
\hline 218 & Western Europe & Langueoc BZ & c. $1800-1500 \mathrm{BC}$ \\
\hline 219 & Western Europe & Narbonnais-Roussiilon & c. $1800-1500 \mathrm{BC}$ \\
\hline 220 & Western Europe & Total group (culture Theiss) & c. $2500-2100 \mathrm{BC}$ \\
\hline 221 & Hamburg & Total group (Tiszapolgár culture) & c. $2500-2100 \mathrm{BC}$ \\
\hline 222 & Germany & Total group (Bodrogkeresztúr culture II) & c. $2500-2100 \mathrm{BC}$ \\
\hline 223 & Austria & Franzhausen (culture Veterov) & c. $1800-1500 \mathrm{BC}$ \\
\hline 224 & Italy & Castiglione, Ragusa & c. $1800-1600 \mathrm{BC}$ \\
\hline 225 & Germany & Германия (culture Unetice) & c. $1700-1400 \mathrm{BC}$ \\
\hline
\end{tabular}

The analysis included 29 odontologic series from the territory of Eurasia (Tabl. 2). The analysis is carried out by means of following signs: diastema $\mathrm{I}^{1}-\mathrm{I}^{1}$ Shov $\mathrm{J}^{1}, \mathrm{M}^{2} \sum 3,3+$, cara $\mathrm{M}^{1},+5$ form on $\mathrm{M}_{1}, 6$ - and 4-forms on $\mathrm{M}_{1}, 4-$ form on $\mathrm{M}_{2}$, DW, Dtc, $2 \mathrm{med}$ (II). Data are subjected to the component and cluster analysis. They were analyzed in 3 steps in order to maximize the number of skeletal samples included in the study. Kozintseva and Kozintseva's statistical package (Museum of Anthropology and Ethnography of name of the Peter the Great, St. Petersburg) has been used.

\section{Results and Discussion}

Measurements of the neurocranium and facial skeleton have been used for many years to provide an assessment of the degree of biological relatedness among samples from past and living populations. Although these measurements are influenced by an unknown combination of hereditary and environmental factors (Cavalli-Sforza and Bodme, 1971), and may be affected by masticatory mechanics (Van Gerven, 1982) and environmental variation (Beals, 1972; Guglielmino-Matessi, Gluckman, \& Cavalli-Sforza., 1979), twin studies (Clark, 1956; Orczykowska-Swiatkowska \& Lebioda., 1975, Saunders, Popovich, \& Thompson. 1980), familial studies (Devor, 1987; Howells, 1966), and worldwide comparisons of craniometric variation have revealed a moderate degree of genetic control (Susanne, 1977), and have demonstrated the utility of such variables for reconstructing patterns of biological interaction between populations (Howells, 1973, 1989; Abdushelishvili, 1982, 2003; Alexseev, 1986).

The analysis 1 . Ten standard measurements from 86 crania were selected for analysis. Vectors for the first three canonical variates are given in table 3 . 
Table 3. Elements of three initial vectors for 86 groups

\begin{tabular}{cccc}
\hline & \multicolumn{3}{c}{$\hat{0}$} \\
\hline 1 & I & II & III \\
\hline 8 & -0.273 & 0.602 & 0.635 \\
17 & 0.306 & -0.456 & -0.425 \\
9 & -0.098 & -0.245 & 0.311 \\
45 & -0.006 & -0.248 & 0.536 \\
48 & 0.716 & -0.046 & 0.275 \\
55 & -0.292 & -0.135 & -0.497 \\
54 & 0.243 & 0.057 & 0.366 \\
51 & -0.347 & -0.063 & -0.186 \\
52 & -0.427 & 0.101 & 0.019 \\
Values & 0.447 & 0.770 & -0.537 \\
& 21.501 & 13.039 & 12.490 \\
\hline
\end{tabular}

As is to be expected, the first canonical vector accounts for the majority (21.6\%) of the intergroup discrimination. The positive weight gives bizygomatic breadth $(0.716)$. The second canonical vector $(13.1 \%)$ are maximum for orbital height $(0.770)$ and cranial length $(0.602)$. The third canonical vector accounts for the $12.5 \%$ of the intergroup. The positive weight gives a cranial length $(0.635)$ and minimal width of a forehead $(0.536)$ in contrast to the negative weight for orbital breadth $(-0.537)$.

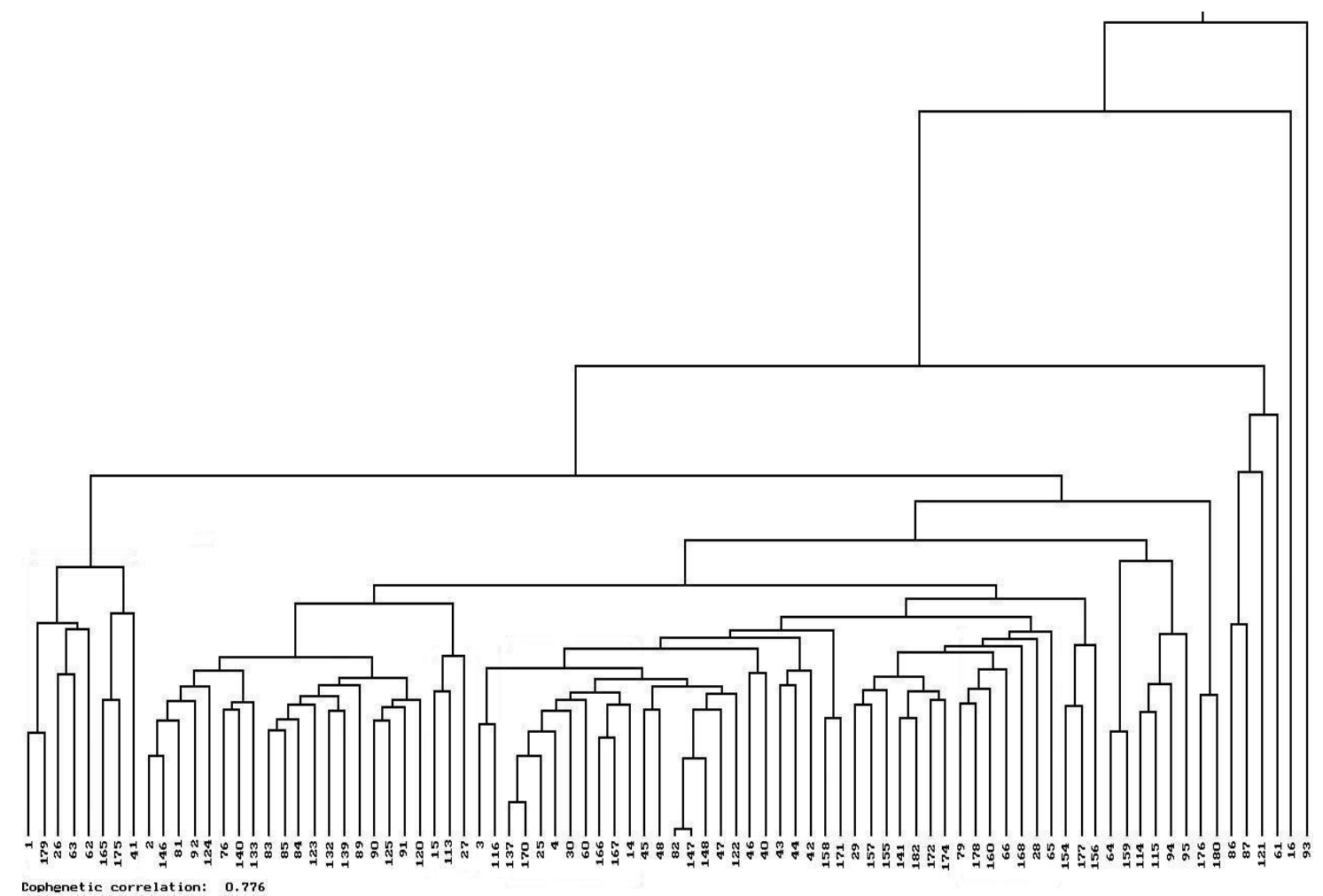

Figure1. Cluster tree based on Mahalanobis $\mathrm{D}^{2}$ distances ( 86 groups of epoch of a neolith and bronze). The analysis 1

The dendrogram gives a visual idea of the relationship between the various groups (figure 1). Cluster analysis provides a different representation of the distance matrix, because it is an unrooted tree whose branches have different lengths. Long branch lengths may be interpreted as an indicator of a large degree of morphological separation, while short branch lengths are indicative of a small degree of morphological separation between 
samples. Affinities among Kura-Araks population samples are rather diffuse. The Armenian highlands sample (Landjik) and sample from Czechia (Bogemia /Corded Ware culture/) exhibit close affinities to one another. The Jericho features a close affinity with those of the Europe samples (cultures Michelsberger and Corded Ware). The Catal Hüyüka sample from Asia Minor serves as a phenetic link between Armenian highlands (Kura-Araks culture), the Crimea (Kemi Oba culture) and Slovakia samples (Corded Ware culture) that feature the closest affinities to one another. In Catal Hüyük the shapes lie closer and to other European forms (Harvig, 2007, Khudaverdyan, 2011a). This suggests that some of the European genes do actually stem from this area. Mediterranean connections from Asia Minor and Georgia are distinctly fixed in Western Europe in the Early Bronze Age. The sample from Anatolia (Catal Hbyska) exhibits affinities to sample to Georgia (Kura-Araks culture: -0.487). The Crimea sample (Kemi Oba culture) and the Armenian highlands (Kura-Araks culture: -0.556) sample exhibit close affinities to one another. Results of the analysis reveal a certain intersample affinities among the samples from Georgia (14, Kura-Araks culture) and Poland (Corded Ware culture). The Kura-Araks culture samples (Armenian highland) and Romania (burials with ochre) are identified as possessing the closest affinities to one another (0.440).

The Kalmykia sample (maikop culture: Evdik I) exhibit closest affinities to samples Cucuteni-Trypillian tribe cultures (aka Tripolye) (from Moldova 147, 148). The Armenian highlands samples (4, Kura-Araks culture) serve as a phenetic link between Moldova samples (Tripolye culture: 0.506) that feature the closest affinities to one another. Among groups, the two geographic samples included (Djarat / Kura-Araks culture/ and Vikhvatintsi /Cucuteni-Trypillian culture/: 0.384) are closest neighbors to each other, showing strong geographic clustering. The sample from Mayak (Tripolye culture) occupies a unique position among Ukraine samples by exhibiting much closer affinities to the Armenian highlands (odontological analysis, Analysis 3). The Anatolia sample (Chatal Hüyük: 0.232) and sample from Romania (Bilche-Zlota: Cucuteni-Trypillian culture) exhibit very close affinities to one another. Northern Caucasus sample (Chalcolithic, Bronze: 0.943) features a moderate affinity with the sample from Ukraine (Cucuteni-Trypillian culture). An examination of this array confirms the patterns of interregional affinities (figure 1). Hence, it is possible to outline the cultural and ethnic communications in antiquity and the known role of the Armenian highlands as the intermediary between ancient area of distribution of Tripolye cultures and the East countries (Passek, 1949; Martiroyan \& Mnacakanyan, 1973; Lang, 2005).

Affinities are closest between the Armenian highland sample from Shengavit (3, Kura-Araks culture), and sample from Volga region (Late Fatianovo). The Armenian highlands sample (4, Kura-Araks culture: 0.446) and the Late Fatianovo sample from Volga region exhibit very close affinities to one another. The results, however, fail to demonstrate even a low-level phenetic affinity between Fatyanovo and either of the Western Europe samples. The sample from Georgia (Tkviavi) match the sample from the Volga region (Abashevskaya culture) (figure 1).

The Armenian highlands sample (4) and the Bronze Age (Pit Grave culture) samples from Dnieper region (0.755) and Ukraine (0.906) exhibit close affinities to one another. The Pit Grave-Catacomb time samples from Kalmykia and Djarat (2, Armenian highlands, 0.094) exhibit very close affinities.

The Catacomb culture samples from the Ukraine and Dnieper are identified as the steppe samples with closest affinities samples from Northern Caucasus (Chalcolithic, Bronze). The Armenian highlands samples (4, Kura-Araks culture: 0.252) and the Bronze Age sample from Kalmykia (Catacomb culture) exhibit very close affinities to one another. If we follow a hypothesis put forward and developed by Gamkrelidze and Ivanov (1984) considering the ancestral home of Indo-European areas of the Anatolian/Armenian highlands and adjoining territories, whence other tribes get into the Northern Black coast both through the Caucasus and through Central Asia and the Volga region (carriers of a Catacomb culture ceremony), it is necessary to assign that movement to Aryan tribes, which were one of the first to get into Black Sea coast steppes through the Caucasus (or possibly by sea?). Though researchers connect this movement with the early Bronze Age, the process quite keeps well within the Catacomb culture. According to all available data from Chernykha (2008), early Catacomb cultures are dated to the beginning of the III millennium BC. This specifies the constant presence in the steppes of Kuro-Araks or of a cultural group to related it, and not transitory migrants. The Catacomb culture made sophisticated arsenical bronze weapons, tools, and ornaments, probably using Caucasian alloying recipes. Among subjects of the steppe Catacomb culture, a significant amount of Caucasian bronze products are revealed (Krupnov, 1966; Trifonov, 1991; Nechitailo, 1991; Pystovalov, 2002). In the II millennium BC Caucasian metal prevailed in northern areas, extending up to Oka. Experts have even allocated a whole stage in the history of metallurgy (from III thousand BC to the middle II thousand BC) to Eastern Europe and named its Caucasian (Nazarov, 2002; Pystovalov, 2002). 
Analysis has shown that it is impossible to deny a some part in the formation of the Catacomb culture to the Pit Grave people (the local population is almost never completely replaced, and some part of it is almost always included in a new culture). It is possible to judge a measure of this participation on the basis of the following data: affinities are closest between the samples Catacomb culture from Kalmykia and Pit Grave culture samples from Ukraine and Dnieper.

From whence came the Catacomb population (or its alien component)? To connect the Catacomb population with any certain culture is not yet possible, but the Mediterranean component certainly added to the Catacomb population from territory of the Near East and the Armenian highlands. Balaresque et al. (2010) proposed an Anatolian origin for the predominant male DNA haplogroup in Europe, known as R1b (Y-DNA). It is necessary to notice that Shevchenko (1986), arguing on the basis of the occurrence of a ceremony of artificial deformation of the head in tribes of the Catacomb cultures, considered that this tradition was brought to the steppe of Eastern Europe from the Mediterranean more likely by Caucasian and through its concrete carriers. Khlopin (1983) connect the Catacomb culture with the Indo-Aryans, because catacomb burial ritual had roots in Southwestern Turkmenistan from the early IV millennium BC (Sumbar cemetery). Fisenko (1966) suggest that the Catacomb people were Proto-Hittites. Kuzmina (1998) also is a supporter of the hypothesis Fisenko. Anthony (2007) supposed Catacomb people to be ancestors of Greeks, while Berzin and Grantovsky (1962), Klejn (1980, 1984, 2010) determine the Indo-Aryans originated from the Catacomb culture.

The samples from Georgia (14, Kura-Araks culture) occupies a unique position among Caucasus samples by exhibiting much closer affinities to Egypt samples (Sakkara II: 0.160; Sakkara I: 0.825). Other researchers also emphasize the close affinities to samples from Egypt (Abdushelishvili, 2003). The Egypt samples (Acmant: 0.178, Badari: 0.588) and Iran (Tepe Gissar II) are identified as possessing the closest affinities to one another.

Let's continue the analysis (2) of 89 series. Vectors for the first three canonical variates are given in table 4. Placement of the samples used in figure 2 determined by the values of canonical vectors I (20.3\%) and II (11.6\%). Vector I has its strongest value nasal breadth (-0.596) and upper facial height (-0.544). Small values correspond to the basic sizes of a neurocranium $(17,9)$. The positive weight (vector II) given for maximum cranial height $(0.532)$ in contrast to the negative weight for maximum bizygomatic breadth $(-0$. 850). The III canonical vector accounts for the $10.3 \%$ of the intergroup discrimination. The positive weight (vector III) given for maximum cranial breadth (0.650), nasal (0.546) and orbital $(0.531)$ height in contrast to the negative weight for maximum cranial length (-0.677), minimal width of a forehead (-0.529) and upper facial height (-0.500).

Table 4. Elements of three initial vectors for 89 and 109 groups

\begin{tabular}{|c|c|c|c|c|c|c|}
\hline & \multicolumn{2}{|c|}{$0^{\lambda}$} & \multirow{2}{*}{$\begin{array}{c}\text { (89 groups) } \\
\text { III }\end{array}$} & \multicolumn{2}{|r|}{$\sigma^{\lambda}(109$} & \multirow{2}{*}{$\begin{array}{c}\text { groups) } \\
\text { III }\end{array}$} \\
\hline & I & II & & I & II & \\
\hline 1 & 0.301 & 0.270 & -0.677 & -0.550 & 0.096 & -0.306 \\
\hline 8 & -0.279 & -0.350 & 0.650 & 0.789 & -0.460 & 0.190 \\
\hline 17 & 0.174 & 0.532 & 0.368 & -0.457 & 0.023 & 0.548 \\
\hline 9 & 0.274 & -0.022 & -0.529 & -0.282 & -0.132 & -0.093 \\
\hline 45 & 0.452 & -0.850 & -0.048 & 0.184 & 0.356 & 0.212 \\
\hline 48 & -0.544 & -0.471 & -0.500 & 0.150 & -0.067 & -1.086 \\
\hline 55 & 0.461 & 0.424 & 0.546 & -0.165 & 0.196 & 1.080 \\
\hline 54 & -0.596 & 0.114 & 0.276 & -0.076 & -0.190 & -0.311 \\
\hline 52 & 0.437 & 0.335 & 0.531 & 0.443 & 0.840 & -0.036 \\
\hline 51 & -0.300 & 0.281 & 0.004 & -0.194 & -0.045 & -0.231 \\
\hline Values & 20.291 & 11.554 & 10.299 & 15.785 & 12.361 & 8.233 \\
\hline
\end{tabular}




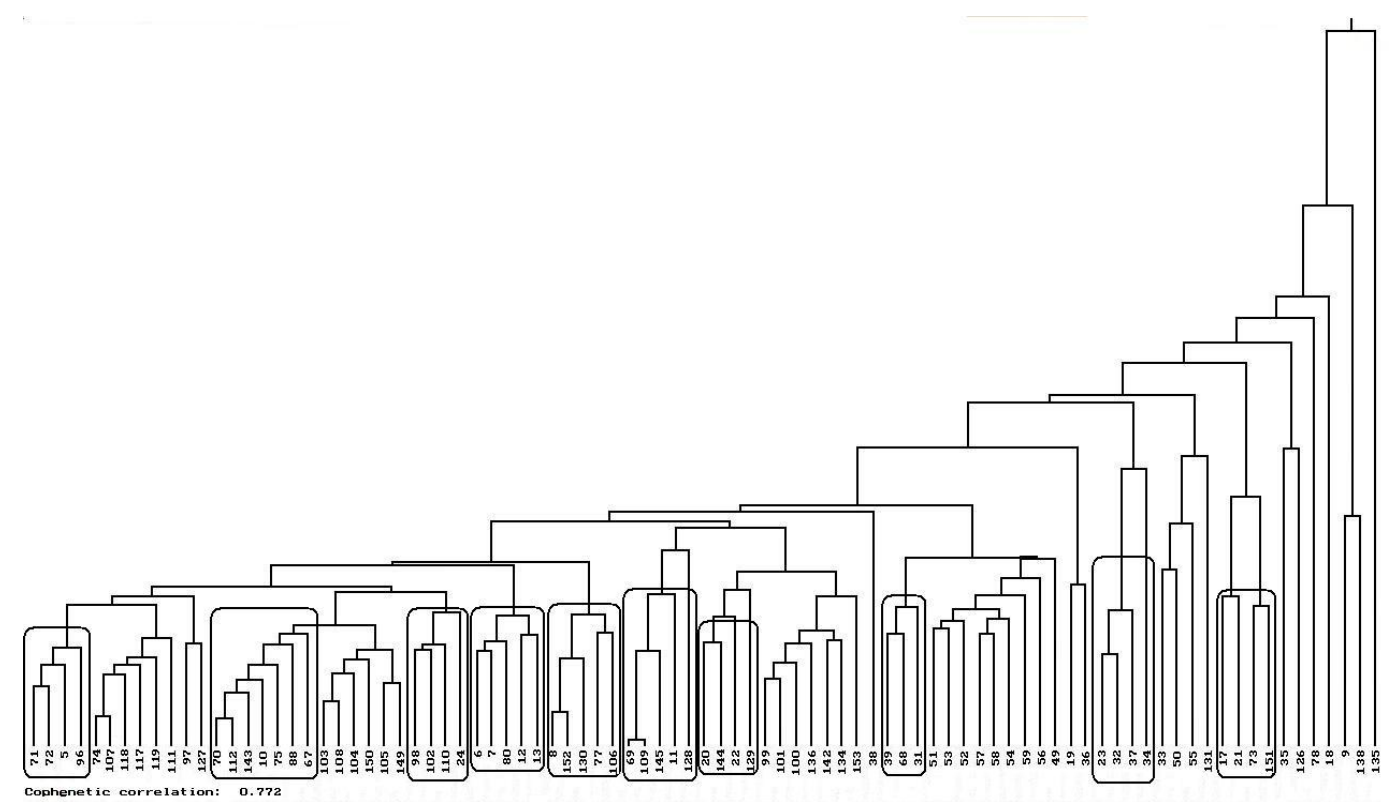

Figure 2. Cluster tree based on Mahalanobis $\mathrm{D}^{2}$ distances ( 89 groups of epoch of a neolith and bronze). The analysis 2

Debets $(1948,1954)$ noted a large carcass gracile Timber Grave culture (Russ. Srubnaya culture) samples as compared with the Pit Grave and allocated among its carriers two anthropological types. Further evidence was provided by the Timber Grave on the western outskirts of the area to the circle of the Mediterranean forms (Konduktorova, 1956, 1969, Kruts, 1976). The presence of the Mediterranean components was marked by Shevchenko (1984, 1986), Khokhlov (2000) in carriers of Timber Grave cultures of the forest-steppe Volga region, and also by Yusupov (1989) in the Southern Urals Mountains. It is reasonable to suppose a new population, carriers of Mediterranean morphological features, reaches into the Middle Bronze Age in the East European Plain. Now one can, by scrupulous comparative analysis of races, cover many biological contacts of the carcass population. Depiction of the similarities of the various groups tested can be seen from the dendrogram. Affinities are closest between the Tajikistan samples from Symbar, Makonimor, Artik from Armenian highland and sample from Saratov region (Timber Grave culture) (figure 2). The Artik (5) sample from Armenian highlands and Timber Grave samples from Volgo-Ural region (Xrichovka: 0.289, Alekseevski: 0.331, Poplavskoe: -0.546 , N.Orlianka I: -0.604, Luzanovka: 0.938) also exhibit close affinities to one another. And the Makonimor sample exhibits affinities to Timber Grave cultures samples from Volgo-Ural region (Poplavskoe: -0.084, Novoselki: -0.570, Studenci: 0.666, Luzanovka: 0.732, Roszestveno I:-0.946), Bashkiria (0.402) and Ukraine (143, flat burials: 0.637). The Symbar sample from the Tajikistan and Timber Grave samples from Volgo-Ural region (N.Orlianka I: -0.173, Roszestveno I: -0.284, Novoselki: 0.942) also exhibit close affinities to one another.

Samples from Armenian highlands (10, Arcvakar), Middle Asia (67: Dzarkytan, 70: Tigrovaya Balka),Western Kazakhstan (Andronovo culture) and Timber Grave samples from Volga region (Uranbash, Krivaya lyka), Ukraine exhibit close affinities (Fig. 2). The Arcvakar sample (AAR) exhibits affinities to ten Timber Grave cultures samples from Volgo-Ural region (Xrichovka et al.: 0.047, N.Orlianka I: -0.249, Pure Jr I: -0.502, Krivaya lyka: 0.504, Alekseevski: -0.755 , Xrichovka: -0.847 , Syezzhe: -0.854 , Novoselki: -0.875 , Studenci: 0.935, Luzanovka: -0.995), Saratov region(-0.497), Volgo-Astrakhan region (0.795), Forest-steppe the Volga region (0.533) and two samples from the Bashkiria (117: -0.585, 118, Old-Jabalaklinsky: -0.077). Also affinities are closest between the Arcvakar sample (CATB) and the sample from the Dnestr region (Kalfa: 0.493, Old Bedrazji: 0.805). The Dzarkytan sample (67) exhibit the closest affinities with the Timber Grave culture from Volga region (Studenci: 0.096, Krivaya lyka: 0.471) and Ukraine (143, flat burials: 0.266, Shirochanski: 0.910). The Tigrovaya Balka (Tajikistan, 70) features a close affinity with the samples of the Don (Jiasirev: 0.055), Volgo-Ural region (Poplavskoe: -0.011, Luzanovka: -0.081, Novoselki: -0.198, Syezzhe: -0.282, Spiridonovka II-Roszestveno I: 0.350, Xrichovka: -0.449, Spiridonovka II: 0.614, N.Orlianka I: -0.926, Xrichovka et al.: 0.968) and Bashkiria (119: 0.251).

The Late Bronze Age sample from the Georgia (Samtavro) exhibits a peripheral association with samples from Don region (129, Beglica) and Ukraine (144, Shirochanski) (figure 2). The Georgia (20, Samtavro /Late Bronze Age - II period/) sample and samples from Volgo-Uralja (Uranbash: 0.757, N.Orlianka I: 0.996) and Ukraine 
(145, Chernyanka and Wide /Timber Grave culture /belozer phase/: -0.304) also exhibit close affinities to one another. The sample from Georgia (22, Samtavro /c. Õ-VI BC/) exhibits affinities to samples to Volgo-Uralja (Roszestveno I: 0.223; N.Orlianka I: -0.470).

The samples from Armenian highlands (8, Noraduz) and Northern Caucasus (77) serve as a phenetic link between Don region (130, nomads of steppe barrows I), Volgo-Uralja (106, Syezzhe) and the Latvia (Kreichi) featuring the closest affinities to one another (figure 2). The Noraduz (AHN) sample from Armenian highlands and Timber Grave samples from Saratov region (-0.425), Volgo-Uralja (Krivaya lyka: 0.368, N.Orlianka I: 0.127, Novoselki: -0.189, Pure Jr I: -0.384, Poplavskoe: -0.568, Studenci: -0.727) and Ukraine (flat burials: -0.711) also exhibit close affinities to one another.

The steppe Timber Grave sample from Volgo-Ural region exhibits close affinities to the two samples from Iran (Tepe Gissar III - Roszestveno I: -0.118, Tepe Gissar III - Uranbash: 0.737; Shar-i-Sotra - Poplavskoe: 0.941).

In 34 the Timber Grave samples from the territory of the Volgo-Ural region the most distinct phenetic affinities to Mediterraneans of the Armenian highlands, Caucasus, Iran and 30 - Central Asia can be found. Thus, on the basis of the analysis craniological series from the Neolithic and Bronze Ages from territory of Eurasia, the judgments of Khokhlov and Mimokhod (2008) about the periodic penetration into northeast areas of the European steppes of different morphological complexes connected with the Mediterranean anthropological type is proved.

The analysis 3. Placement of the 109 samples used in figure 3 determined by the values of canonical vectors I $(15.8 \%)$ and II (12.4\%) (Table 4). The positive weight (vector I) given for maximum cranial breadth $(0.789)$ is in contrast to the negative weight for maximum cranial length $(-0.550)$. Vector II has its strongest value orbital height $(0.840)$. The III canonical vector accounts for the $8.3 \%$ of the intergroup discrimination. Vector III has its strongest value an upper facial height (-1.086) and nasal (1.080), cranial height (0.548).

The Mediterranean samples from the Armenian highlands, Iran, and Caucasus (Late Bronze Age) tend to tie with samples across the entire range from east to west. This is reflected by the degree of phenetic cohesion found among samples, regardless of the geographic distances that separate them. The Armenian highlands, Georgia, Iran samples and sample from Western Europe exhibit close affinities (figure 3). Results of the analysis reveal a certain intersample affinities among the samples from Armenian highland (5, Artik), Tajikistan (Makonimor, Symbar), Saratov region (Timber Grave culture) and Europe (188, Sardinia; 192, Grands Causses Lozere; 185, Ponte San Pietro, Rinaldone; 169, Poland: culture Zlota) (figure 3). The Armenian highlands sample (Noraduz) exhibits affinities to four Bronze Age samples from France (192, Grands Causses Lozere: -0.098, 193, Causses d'Aveyron: -0.114), Silesia (212, -0.107) and Hamburg (221, Tiszapolgár culture: 0.283). Affinities are closest between the Orom sample and the samples from Romania (161, Balintesh (culture Monteoru: 0.699), France (193, Causses d'Aveyron: 0.758) and Silesia (212, 0.564). The Armenian highlands (13) sample and samples from Hamburg (221, Tiszapolgár culture: 0.071; 196, Mecklenburg: 0.965), France (193, Causses d Aveyron: $0.526)$ and Silesia $(212,0.684)$ also exhibit close affinities to one another.

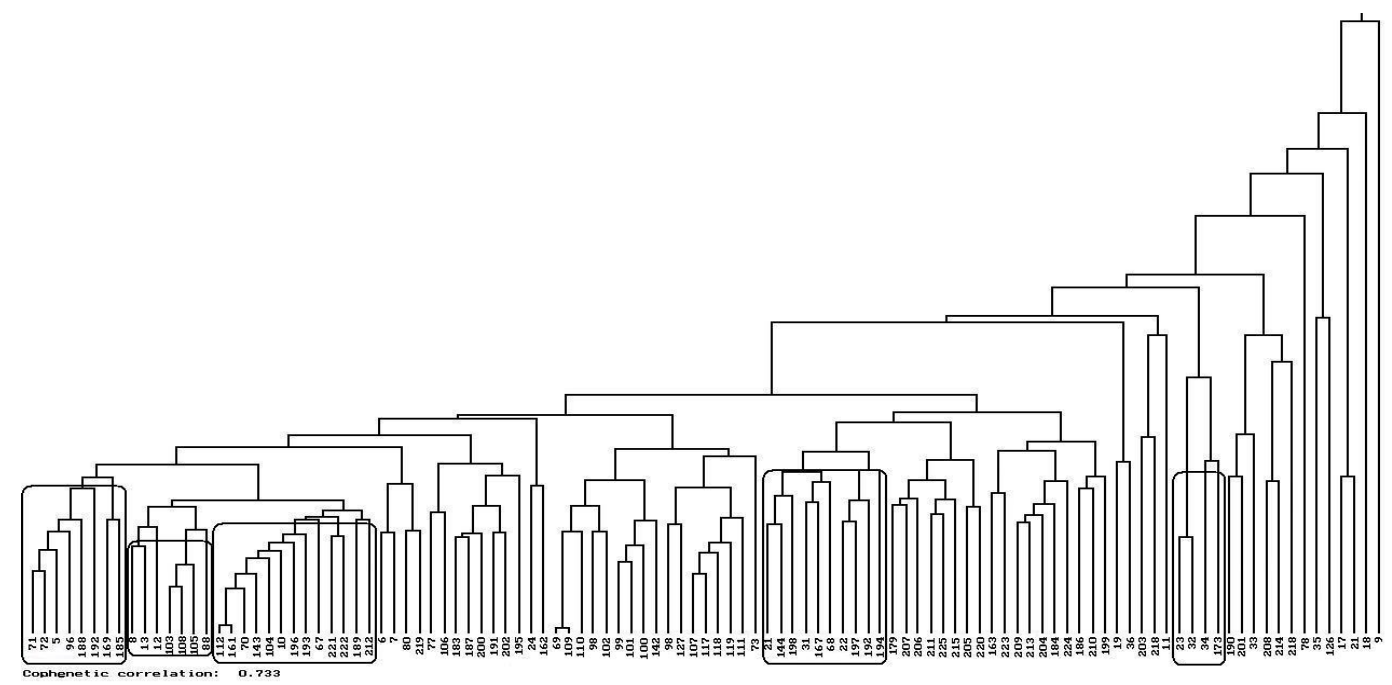

Figure 3. Cluster tree based on Mahalanobis $\mathrm{D}^{2}$ distances (109 groups of epoch of a neolith and bronze). The analysis 3 
One can see a clear link between the Armenian highlands samples and the Western Europe samples (the Arcvakar sample - 17 close phenetic links are revealed). The samples from the Georgia (Samtavro/Late Bronze Age - II period) and Iran (Tepe Gissar III), Uzbekistan (Sapallitepe) are identified as the samples with closest affinities samples from Ukraine (Shirochanski) and Poland, Germany (Corded Ware culture) in particular (figure 3 ). This suggests that some of the European genes do actually stem from this area. So, mediterranean connections from Armenian highlands, Georgia and Central Asia are distinctly fixed in Western Europe and in the Middle-Late Bronze Age.

For odontologic analysis it was necessary to select such feature set which, on the one hand, adequately enough would define a direction of intergroup variability in territory of Eurasia, and, on the other hand, would be accessible in publications of some the authors containing a material for the comparative analysis. In total, the analysis included 29 odontological samples from the territory of Eurasia (Table 2). Statistical comparisons were made within and between the different periods (Bronze and Iron Age tombs) from Eurasia. There was little difference dentally between individuals from corresponding time periods from Armenian highland, although it should be noted that groups were represented by small sample sizes, which may explain the lack of statistically significant MMD values (so we have united Bronze Ages from Armenian highlands).

Table 2. Eurasian odontologic samples

\begin{tabular}{|c|c|c|c|}
\hline & Site (s) & Sample name & Date \\
\hline 1 & Armenian highland & Total group I (Landjik-Black Fortress) & c. $3000-2000 \mathrm{BC}$ \\
\hline 2 & Armenian highland & Total group II & c. $3000-1000 \mathrm{BC}$ \\
\hline 3 & Georgia & Total group & c. $3000-1000 \mathrm{BC}$ \\
\hline 4 & Kalmykia & Total group (Pit Grave culture) & c. $3000 \mathrm{BC}$ \\
\hline 5 & Volga region & Taktalachuks & c. $2000-1000 \mathrm{BC}$ \\
\hline 6 & Volga region & Total group (Fatianovo culture) & c. $2000-1500 \mathrm{BC}$ \\
\hline 7 & Volga region & Total group (Balanovo culture) & c. $2000-1500 \mathrm{BC}$ \\
\hline 8 & Volga region & Krivaya lyka (Pit Grave culture) & c. $3000 \mathrm{BC}$ \\
\hline 9 & Volga region & Total group (Potapovsky culture) & c. $3000 \mathrm{BC}$ \\
\hline 10 & Volga region & Total group (Petrovskaya culture) & c. $3000 \mathrm{BC}$ \\
\hline 11 & Volga region & Total group (Pokrovkaya culture) & c. $3000 \mathrm{BC}$ \\
\hline 12 & Ural & Total group I (Sintashtinskaya culture) & c. $3000-2000 \mathrm{BC}$ \\
\hline 13 & Ural & Total group II (Sintashtinskaya culture) & c. $3000-2000 \mathrm{BC}$ \\
\hline 14 & Ural & $\begin{array}{c}\text { Total group (Timber Grave and Alakul } \\
\text { cultures) }\end{array}$ & c. $1800-1100 \mathrm{BC}$ \\
\hline 15 & Ural & Total group (Alakul culture) & c. $1800-1100 \mathrm{BC}$ \\
\hline 16 & Ural & Total group (Timber Grave culture) & c. $1800-1100 \mathrm{BC}$ \\
\hline 17 & Altai & Total group (culture Andronovo) & c. $1700-1200 \mathrm{BC}$ \\
\hline 18 & Siberia & $\begin{array}{c}\text { Forest-steppe Barabinskaya (culture } \\
\text { Andronovo) }\end{array}$ & c. $1700-1200 \mathrm{BC}$ \\
\hline 19 & Siberia & Total group (Tagarskaya culture) & c. X - VIII BC \\
\hline 20 & Turkmenia & Altyn- Depe & c. $2500-2100 \mathrm{BC}$ \\
\hline 21 & Turkmenia & Total group (painted ceramics culture) & c. $5000-3000 \mathrm{BC}$ \\
\hline 22 & Turkmenia & Gonur-Depe & c. $3000-2000 \mathrm{BC}$ \\
\hline 23 & Uzbekistan & Sapallitepe & c. $2000-1000 \mathrm{BC}$ \\
\hline 24 & Ukraine & Total group (Dnieper-Donets Culture) & c. $5000-2000 \mathrm{BC}$ \\
\hline 25 & Ukraine & Total group (Pit Grave culture) & c. $4000-3000 \mathrm{BC}$ \\
\hline 26 & Ukraine & Total group (Cucuteni- Trypillian culture) & c. $4000-3000 \mathrm{BC}$ \\
\hline 27 & Kareliya & Oleni ostrov & c. $6000-2000 \mathrm{BC}$ \\
\hline 28 & Latvia & Total group & c. $5000-3000 \mathrm{BC}$ \\
\hline 29 & Latvia & Kiwytkalnsk (Corded Ware culture) & c. $2000 \mathrm{BC}$ \\
\hline
\end{tabular}

The analysis 1 . Ten standard nonmetric traits from 11 crania were selected for analysis. Components for the first three factors are given in table 5 . As is to be expected, the first component accounts for the majority $(34.8 \%)$ of the intergroup discrimination. Taking into account character of connection of attributes in this component, it is possible to tell that the large values till I coordinate axes correspond to morphological groups with 4- form on $\mathrm{M}_{1}$ (0.853), $\mathrm{I}^{1}-\mathrm{I}^{1}$ (diastema, 0.782), Shov $\mathrm{I}^{2}$ (Shoveling, 0.698). The second component $(25.4 \%)$ are maximum for +5 on $\mathrm{M}_{1}(0.827)$, Carabelli trait $\left(\right.$ Cara $\left.\mathrm{M}^{1} / 2-5 /, 0.650\right)$ and 4-form on $\mathrm{M}_{2}(0.592)$. The third component accounts 
for the $20.1 \%$ of the intergroup. The positive weight gives a $\mathrm{M}^{2} \sum 3,3+$ (RHy) $(0.742)$. Thus, on the basis of the given characteristic of morphological complexes it is possible to mention, that groups are differentiated under the form to a signs reducing character.

Table 5. Elements of three initial components for 11 groups

\begin{tabular}{lccc}
\hline & $\mathrm{I}$ & $\mathrm{II}$ & $\mathrm{III}$ \\
\hline $\mathrm{I}^{1} \mathrm{I}^{1}$ & 0.782 & -0.455 & -0.042 \\
$\mathrm{Shov} \mathrm{I}^{2}$ & 0.698 & -0.301 & 0.560 \\
$\mathrm{M}^{2} \sum 3,3+$ & 0.279 & -0.113 & 0.742 \\
$\mathrm{Cara} \mathrm{M}^{1}(2-5)$ & -0.227 & 0.650 & 0.455 \\
$\mathrm{M}_{1} 4$ & 0.853 & 0.079 & -0.447 \\
$+5 \mathrm{M}_{1}$ & 0.440 & 0.827 & 0.190 \\
$\mathrm{M}_{2} 4$ & 0.529 & 0.592 & -0.310 \\
Values & 34.701 & 25.315 & 20.074 \\
\hline
\end{tabular}

The final step in analysis was to generate intersample affinities using only the above six traits to affirm their influence. Groups are in pairs and compared with the help of the not weighed paired-group method. The dendrogram gives a visual idea of the relationship between the various groups (figure 4).

During a bronze epoch southern grace odontologic the complex has been extended to big enough territory covering Caucasus, Central Asia and the Eastern Europe. The antiquity of this layer goes back to earlier time from areas of the Near East (Dahlberd, 1960; Pilloud, 2009). Results of the analysis reveal a certain intersample affinities among the samples from Armenian highland (1, Landjik-Black Fortress), Kalmykia (4, Pit Grave culture) and Volga region (8, Krivaya lyka /Pit Grave culture/) (figure 4). Necessary note, that results craniological the analysis on a wide geographical and cultural background have revealed relations of representatives Kuro-Araksa of the Armenian highlands with tribes Pit Grave culture (Analysis 1).

The Volga region sample (6, Fatianovo culture) and the sample from Latvia (28) exhibit close affinities to one another. The Kiwytkalnsk (29, Latvia) features a close affinity with those of the Turkmenia samples (21, painted ceramics culture). Affinities are closest between the Middle Asia samples from Altyn- Depe (20) and Sapallitepe (23).

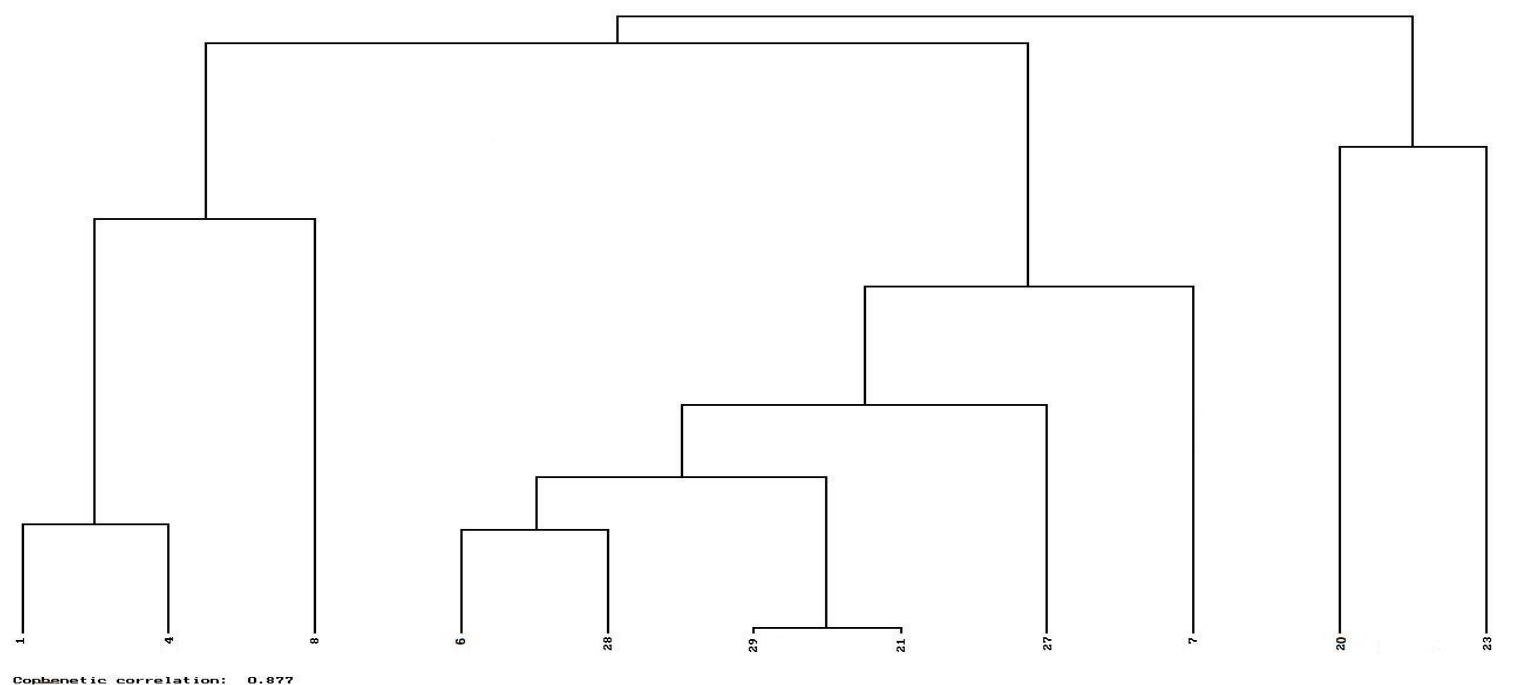

Figure 4. Cluster tree (11 groups of epoch of a neolith and bronze). The analysis 1

Let's continue the analysis (2) of 20 series. Placement of the samples used in figure 5 determined by the values of components I (32.9\%) and II (22.5\%) (Table 6). Component I has its strongest value and geniculate fold metaconulid (DW, 0.767), Distal comb trigonidum (Dtc, 0.747) and $\mathrm{M}^{2} \sum 3,3+$ (RHy, 0.646). The positive weight (component II) given for maximum 4-form on $\mathrm{M}_{2}(0.749)$ and Carabelli trait (Cara $\left.\mathrm{M}^{1} / 2-5 /, 0.621\right)$. The III component accounts for the $16.7 \%$ of the intergroup discrimination. Component III has its strongest value an 2med (II) (0.755). 
Table 6. Elements of three initial components for 20 groups

\begin{tabular}{lccc}
\hline & I & II & III \\
\hline $\mathrm{M}^{2} \sum 3,3+$ & 0.646 & 0.147 & -0.284 \\
Cara $^{1}(2-5)$ & 0.269 & 0.621 & 0.483 \\
$\mathrm{M}_{1} 4$ & 0.710 & 0.558 & 0.037 \\
$\mathrm{M}_{2} 4$ & -0.079 & 0.749 & -0.444 \\
$\mathrm{DW}$ & 0.767 & -0.446 & -0.185 \\
$2 \mathrm{med}(\mathrm{II})$ & 0.388 & -0.118 & 0.755 \\
Dtc & 0.747 & -0.282 & -0.214 \\
Values & 32.807 & 22.457 & 16.618 \\
\hline
\end{tabular}

The Armenian highlands sample (2) exhibit closest affinities to sample from Turkmenia (Gonur-Depe) (figure 5). The Balanovo culture sample from the Volga region (7) are identified as the steppe samples with closest affinities samples from Ukraine (26, Cucuteni-Trypillian culture) in particular. Intersample affinities among samples the Georgia (3) and Ural (16, Timber Grave culture) also show up. The Turkmenia sample (21, painted ceramics culture) and the Bronze Age sample from Ukraine (25, Pit Grave culture) exhibit very close affinities to one another. Analysis has shown close affinities samples from Turkmenia (20, Altyn-Depe) and Altai (17, culture Andronovo).

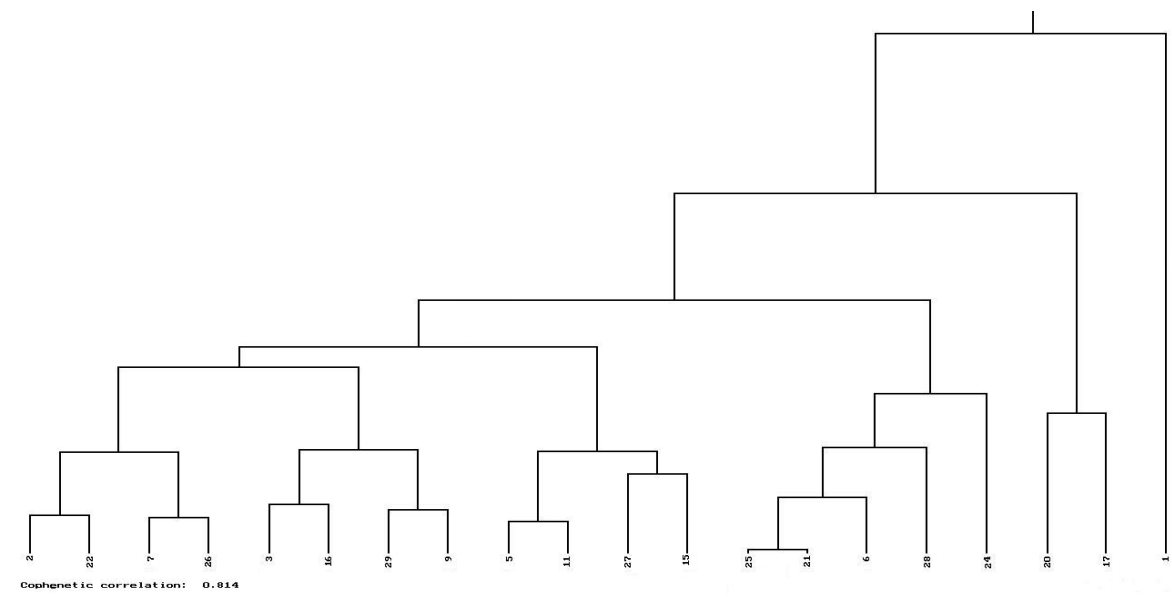

Figure 5. Cluster tree (20 groups of epoch of a neolith and bronze). The analysis 2

The analysis 3. Placement of the 26 samples used in figure 6 determined by the values of components I (38.9\%) and II (22.3\%) (Table 7). The positive weight (components I) given for maximum $\mathrm{M}^{2} \sum 3,3+(\mathrm{RHy}, 0.821)$, 4-form on $\mathrm{M}_{1}$ and geniculate fold metaconulid (DW, 0.681). Component II has its strongest value 4-form on $\mathrm{M}_{2}$ (0.920). The III component accounts for the $17.3 \%$ of the intergroup discrimination. Component III has its strongest value an Carabelli trait (Cara $\left.\mathrm{M}^{1} / 2-5 /, 0.833\right)$.

Table 7. Elements of three initial components for 26 groups

\begin{tabular}{lccc}
\hline & I & II & III \\
\hline $\mathrm{M}^{2} \sum 3,3+$ & 0.821 & 0.192 & 0.168 \\
$\mathrm{Cara}^{1}(2-5)$ & -0.482 & -0.254 & 0.833 \\
$\mathrm{M}_{1} 4$ & 0.756 & 0.041 & 0.307 \\
$\mathrm{M}_{2} 4$ & -0.038 & 0.920 & 0.206 \\
$\mathrm{DW}$ & 0.681 & -0.406 & 0.058 \\
Values & 38.865 & 22.297 & 17.245 \\
\hline
\end{tabular}


When considering the dendrogram, note the significant similarity of the ancient groups of the Armenian highlands (1), Ural $(13,15,12)$, the Volga region $(11,10)$, Kalmykia (4) and Siberia (18). Possibly, it can be extrapolated on the big anthropological generality in which processes of difficult ethnocultural interactions proceeded. All groups have in a basis southern grace odontologic the complex (Khudaverdyan, 2009; Zubova, 2010; Kitov, 2011). So, the Bronze Age sample from the Armenian highlands (1) exhibit the closest affinities with the sample with Ural (13, Sintashtinskaya culture) (figure 6). Sample from Ukraine (26, Cucuteni-Trypillian culture) compare more closely to sample from the Armenian highlands (2) culture. Results odontologic and craniological researches as a whole coincide.

Gene flow is one of many potential historical factors affecting human variation. In the present study, we examined the potential effects of gene flow by among the popuation groups of Eurasia. These analyses provide abundant evidence in support of a migration of population from the Near East. This scenario is consistent with recent genetic studies supporting a Near Eastern contribution to the European gene pool (the great majority of the $\mathrm{Y}$ chromosomes of Europeans have their origins in the Neolithic expansion) (Richards et al., 2000, Chikhi et al., 2002, Balaresque et al., 2010).

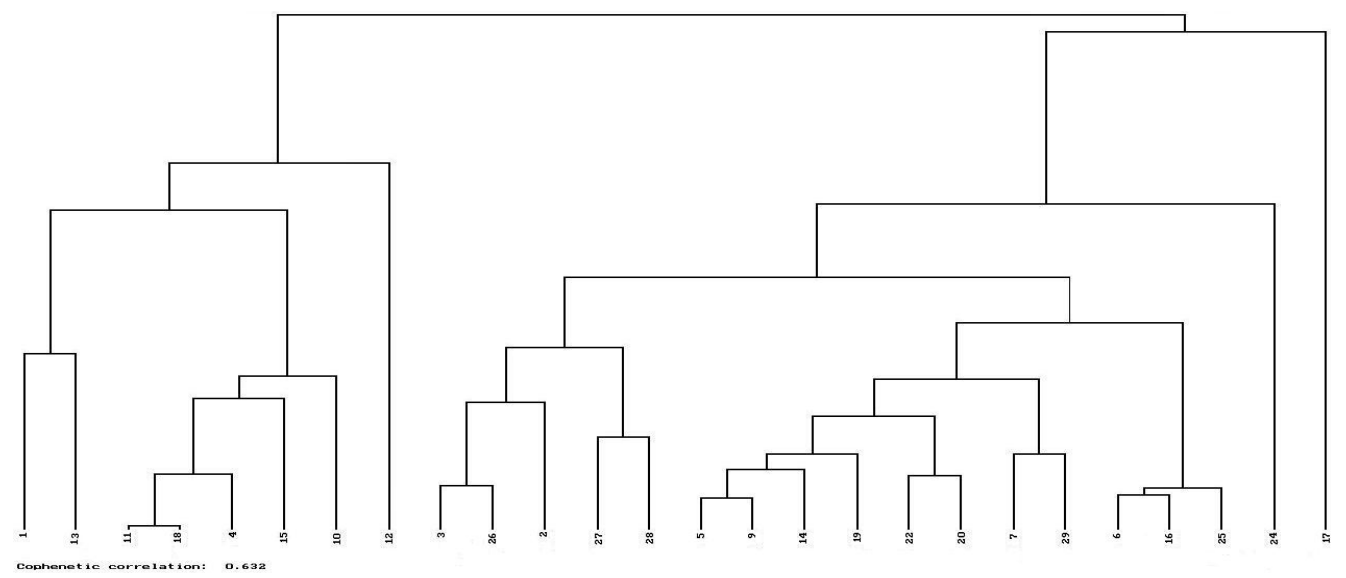

Figure 6. Cluster tree (26 groups of epoch of a neolith and bronze). The analysis 3

If true, it is suggested that the dispersal of the Indo-European languages have been accompanied by migration and some gene flow from the Armenian highlands homeland to the various historical seats of the Indo-European languages. The different rates of genetic drift and external gene flow may have contributed to the morphological differentiation and diversification amongst the different Eurasian populations. Cluster analysis has revealed a craniological series having analogies (on a complex of craniometric, odontologic characters) with representatives of the population of the Armenian highlands, the Caucasus, the Near East and Central Asia. The initial starting area (or one of the intermediate areas), as indicated by the anthropological data, would seem to be the Armenian highlands, and the Caucasus as a whole (Figure 7).

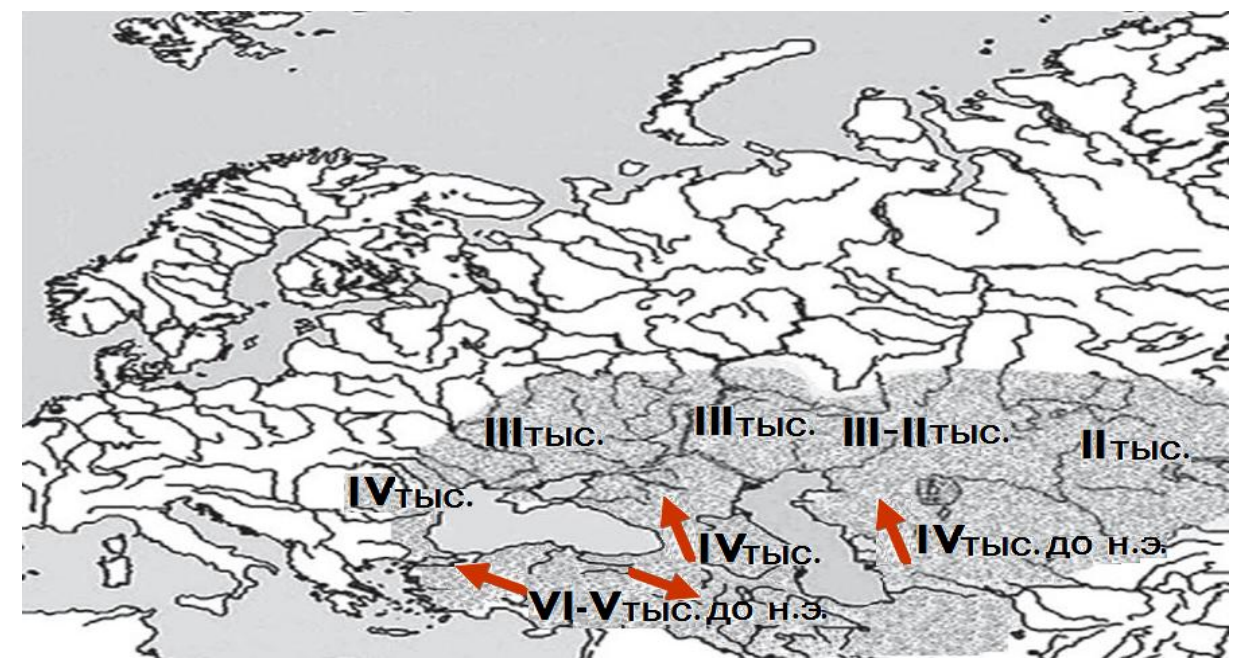

Figure 7. Major diffusion routes the Mediterranean groups. 
It is easy to explain this extensive movement by the Mediterraneans in antiquity by demographic pressure, starting with the emergence of Asia Minor as a center and the development of a production-oriented economy. The anthropological facts revealed by us also have a historical basis, as the distribution of genetic markers is connected with resettlement, and the mixture of tribes is supported by concrete historical and cultural phenomena.

\section{References}

Abdushelishvili, M. G. (1982). Anthropology of the population of Cancasus in a Bronze Age. Tbilisi.

Abdushelishvili, M. G. (2003). Anthropology of the ancient and modern people of Caucasus. In T. I. Alexeeva (Ed.), Anthropology horizons (pp. 248-265). Moscow: Science.

Alexeev, V. P. (1986). To the characteristic of morphological specificity of the Caucasian people on craniometrical data. In V. P. Alexeev (Ed.), Problems of anthropology of the ancient and modern population of the Soviet Asia (pp. 27-56). Novosibirsk: Science.

Anthony, D. W. (2007). The horse, the wheel and language: How Bronze-Age riders from the Eurasian steppes shaped the modern world. Princeton and Oxford: Princeton University Press.

Balaresque, P., Bowden, G. R., Adams, S. M., Leung, H., King, T. E., Jobling, M. A. ... Jobling, M. A. (2010). A Predominantly Neolithic Origin for European Paternal Lineages. PLoS Biology, 8(1), 1-9. http://dx.doi.org/10.1371/journal.pbio.1000285

Beals, K. L. (1972). Head form and climatic stress. American Journal of Physical Anthropology, 37, 85-92. http://dx.doi.org/10.1002/ajpa.1330370111

Berzin, E., \& Grantovsky, E. (1962). Kinsman of Indians on Black Sea shores. Soviet Land (publ. by the Soviet Embassy in India), $X V(10), 26-27$.

Cavalli-Sforza, L. L., \& Bodmer, W. F. (1971). The genetics of human populations. San Francisco: W. H. Freeman.

Chernykh, E. N. (2008). Formation of the Eurasian "steppe belt" of stockbreeding cultures: viewed through the prism of archaeometallurgy and radiocarbon dating. Archaeology. Ethnology \& Anthropology of Eurasia, 35(3), 36-53. http://dx.doi.org/10.1016/j.aeae.2008.11.003

Chicki, L., Nichols, R. A., Barbujani, G., \& Beaumont, M. A. (2002). Y genetic data support the Neolithic Demic Diffusion Model. Proceedings of the National Academy of Sciences, 99, 11008-11013. http://dx.doi.org/10.1073/pnas.162158799

Clark, P. J. (1956). The heritability of certain anthropometric characters as ascertained from measurements of twins. American Journal of Human Genetics, 8, 49-59.

D'iakonov, I. M. (1985). On the Original Home of the Speakers of Indo-European. Journal of Indo-European Studies, 13, 92-174.

D'iakonov, I. M. (1999). The Paths of History. Cambridge University Press.

Dahlberg, A. A. (1960). The Dentition of the First Agriculturists (Jarmo, Iraq). American Journal of Physical Anthropology, 18(4), 243-256. http://dx.doi.org/10.1002/ajpa.1330180402

Debets, G. F. (1948). Paleoantropologia SSSR. Trudy Instituta Etnografii, N.S., IV. Moscow- Leningrad.

Debets, G. F. (1954). Paleoanthropology materials from burials Srubnaja cultures of Average Volga. Materials and researches on archeology of the USSR, 42, 485-499.

Devor, E. J. (1987). Transmission of human craniofacial dimensions. Journal of Craniofacial Genetics and Developmental Biology, 7, 95-106.

Fisenko, V. A. (1966). On the origins and chronology of the Catacomb-grave culture. Saratov: Sratovskogo universiteta.

Gamkrelidze, T. V., \& Ivanov, V. V. (1981). Migrations of tribes - carriers Indo-European dialects - from initial territory of moving in the Near East in historical places of their dwelling in Eurasia. Herald of Ancient History, 2, 25-33.

Gamkrelidze, T. V., \& Ivanov, V. V. (1984). Indo-European language and Indo-Europeans. Tbilisi: Tbilisi University.

Gamkrelidze, T. V., \& Ivanov, V. V. (1990). The early history of Indo-European languages. Scientific American, 262, 110-116. http://dx.doi.org/10.1038/scientificamerican0390-110 
Gray, R. D., \& Atkinson, Q. D. (2003). Language-tree divergence times support the Anatolian theory of Indo-European origins. Nature, 426(6965), 435-439. http://dx.doi.org/10.1038/nature02029

Guglielmino-Matessi, C. R., Gluckman, P., \& Cavalli-Sforza, L. L. (1979). Climate and the evolution of skull metrics in man. American Journal of Physical Anthropology, 50, 549-564.

Harvig, L. (2007). Neolithization and the human body. EAA Summer School eBook, 1, 47-54

Howells, W. W. (1966). Variability in family lines versus population variability. Transactions of the New York Academy of Sciences, 134, 624-631. http://dx.doi.org/10.1111/j.1749-6632.1966.tb43050.x

Howells, W. W. (1973). Cranial variation in man: a multivariate analysis of patterns of difference among recent human populations. Papers of the Peabody Museum of Archaeology and Ethnology. Cambridge, MA: Harvard University Press.

Howells, W. W. (1989). Skull shapes and the map: craniometric analyses in the dispersion of modern Homo. Papers of the Peabody Museum of Archaeology and Ethnography. Cambridge, MA: Harvard University.

Ivanov, V. V. (2004). Twenty years later. About arguments in favour of moving of carriers Indo-European dialects from the ancient Near East. In N. A. Dubova (Ed), At civilisation sources (pp. 41-67). Moscow.

Khlopin, I. N. (1970). Problems of an origin of culture of steppe bronze. Short messages of Institute of archeology Academy of Sciances USSR, 122, 54-68.

Khlopin, I. N. (1983). Southwest Turkmenia during an epoch of Late Bronze (on materials of Sumbar burial). Leningrad: Science.

Khohlov, A. A. (2000). Craniological materials Srubnaja cultures of the south of the Average Volga region. In S. Efimova (Ed.), The people of Russia: from the past to the present (pp. 217-242). Moscow.

Khokhlov, A. A., \& Mimokhod, R. A. (2008). Craniology the population of steppe Ciscaucasia and the Volga region in post Catacomb time. Anthropology bulletin, 16, 44-70.

Khudaverdyan, A. Yu. (2008). Indo-Europeans Migrations: The Origin, Moving From the Point of View of Anthropology. Indian Journal of Physical Anthropology and Human Genetics, 27(1-2), 183-200.

Khudaverdyan, A. Yu. (2009). The bronze population of Armenian highland. Ethnogenesis and ethnic history. Yerevan: Van Aryan.

Khudaverdyan, A. Yu. (2011a). Migrations in the Eurasian steppes in the light of paleoanthropological data. The Mankind Quarterly, LI(4), 387-463.

Khudaverdyan, A. Yu. (2011b). Indo-European migrations: their origin from the point of view of odontology. The Anthropologist, 13(2), 75-81.

Kitov, E. P. (2011). Paleoanthropology of the population of Southern Mountains Urals of a bronze epoch. Diss. $\mathrm{PhD}$. Moscow.

Klejn, L. S. (1980). Where did the Aryans come into India from?. Vestnik Leningradskogo Universiteta, 20, 35-39.

Klejn, L. S. (1984). The coming of Aryans: who and whence?. Bulletin of the Deccan College Research Institute (Pune), 43, 57-72.

Klejn, L. S. (1990). Early Indo-European in the Caucasus and Northpontic steppes. In G. Areshyan, \& S. Esayan (Eds.), Interdisciplinary researches culture genesis and ethnogenesis the Armenian uplands and adjacent areas (pp. 162-175). Yerevan: Yerevan University.

Klejn, L. S. (2010). Time of centaurs. A steppe ancestral home of Greeks and Arius. Samkt-Peterburg.

Konduktorova, T. S. (1956). Materials on the paleoanthropology of the Ukraine. Paleoa Anthropological material of an epoch of bronze (the Zaporozhye area). Anthropological publications, 33, 167-170.

Konduktorova, T. S. (1969). Anthropological shape of tribes of territory of Ukraine during a bronze epoch. Materials of anthropology of Ukraine, 4, 33-56.

Kruts, S. I. (1976). Anthropological features of the population Srubnaja cultures of territory of Ukraine. Eneolith and a bronze age of Ukrain. Kiev.

Kuzmina, E. E. (1998). Cultural connections of the Tarim Basin people and pastoralists of the Asian steppes in the Bronze Age. In V. H. Mair (Ed.), The Bronze Age and Early Iron Age peoples of Eastern Central Asia. 
(Vol. I, pp. 63-93). The Institute for the Study of Man in collaboration of the University of Pennsylvania Museum Publications.

Kuzmina, E. E. (2008). Arias a way on the south. Moscow - St. Petersburg.

Lang, J. (2005). Armenians. The people creator. Riddles of ancient civilisations. Moscow.

Mallory, J. P. (1998). A European perspective on the Indo-Europeans in Asia. In V.H. Mair (Ed.) The Bronze Age and Early Iron Age Peoples of Eastern Central Asia. Washington, DC: Institute for the Study of Man. Journal of Indo-European Studies Monograph, 1(26), 175-201.

Martin, R. (1928). Lehrbuch der Anthropologie. Zweiter Band: Kraniologie, Osteologie. Jena: Gustav Fischer Verlag.

Martiroyan, A. A., \& Mnacakanyan, A. O. (1973). Prierevansky treasure of ancient bronze. Short messages of Institute of archeology Academy of Sciances USSR, 134, 122-127.

Merpert, N. I. (1974). The most ancient cattlemen Volgo-Ural interfluve. Moscow.

Nazarov, A. S. (2002). Metal working at tribes me and Catacomb cultures of a steppe zone of Black Sea. In E. V. Iarovoi (Ed.), Most ancient of a generality of farmers and cattlemen of Northern Black Sea Coast (IV millennium BC - IV centuries $C E$ ) (pp. 122-129). Tiraspol.

Nechitailo, A. L. (1991). Communications of the population of steppe Ukraine and the North Caucasus during a bronze epoch. Kiev.

Orczykowska-Swiatkowska, Z., \& Lebioda, H. (1975). Variability of cranial shape in twins. Stud Phys Anthropol 1: 21-30.

Passek, T. S. (1949). Periodization Tripol settlements. Kiev.

Pilloud, M. A. (2009). Community Structure at Neolithic Çatalhöyük: Biological Distance Analysis of Household, Neighborhood, and Settlement. Diss. PhD. Ohio, The Ohio State University.

Pystovalov, S. (2002). Development of cattle breeding economy in Northern Black Sea Coast during an epoch of a neolith-late of bronze. In E.V. Iarovoi (Ed.), Most ancient of a generality of farmers and cattlemen of Northern Black Sea Coast (IV millennium BC - IV centuries CE) (pp. 101-104). Tiraspol.

Renfrew, C. (1987). Archaeology and Language: The Puzzle of Indo-European Origins. N.Y.: Cambridge University Press.

Renfrew, C. (1998). The Tarim Basin, Tocharian, and Indo-European origins. The Bronze Age and Early Iron Age Peoples of Eastern Central Asia. In V. H. Mair (Ed.), Washington, DC: Institute for the Study of Man. Journal of Indo-European Studies Monograph, 26(1), 202-212.

Richards, M., Macaulay, V., Hickey, E., Vega, E., Sykes, B., Guida, V., \& Bandelt, H. J. (2000). Tracing European founder lineages in the Near Eastern mtDNA pool. American Journal of Human Genetics, 67, 1251-1276.

Rightmire, G. P. (1969). On the computation of Mahalanobis' generalized distance $\left(\mathrm{D}^{2}\right)$. American Journal of Physical Anthropology, 30(1), 157-160. http://dx.doi.org/10.1002/ajpa.1330300121

Safronov, V. A. (1989). Indo-European ancestral homes. Gorky.

Sarianidi, V. I. (1998a). Margiana and Protozoriastrism. Athens, Kapon editions.

Sarianidi, V. I. (1998b). Myths of Ancient Bactria and Margiana on its Seals and Amulets. Moscow.

Sarianidi, V. I. (2010). Long before Zaratushtra (Archaeological evidences of Protozoroastrianizm in Bactria and Margiana). Moscow: Srary sad.

Saunders, S. R., Popovich, F., \& Thompson, G. W. (1980). A family study of cranio-facial dimensions in the Burlington Growth Centre sample. American Journal of Orthodontics, 78, 394-403. http://dx.doi.org/10.1016/0002-9416(80)90020-2

Schwidetzky, I., \& Rösing, F. (1990). Vergleichend-statistische Untersuchungen zur Anthropologie von Neolithikum und Bronzezeit. Homo, 40(1/2), 4-45.

Shevchenko, A. B. (1984). Paleoanthropology data to a question on a population origin Srubnaja a cultural-historical generality. In I. Gokhman (Ed.), Problems of anthropology of the ancient and modern population of Eurasia (pp. 55-73). Leningrad: Science. 
Shevchenko, A. B. (1986). Anthropology of the population of South Russian steppes during a bronze epoch. In I. Gokhman (Ed.) Anthropology of the modern and ancient population of the European part of the USSR (pp. 121-215). Leningrad: Science.

Susanne, C. (1977). Heritability of anthropological characters. Human Biology, 49, 573-580.

Trifonov, W. A. (1991). Steppe near Kuban during an epoch of eneolithic-average bronze (periodization). In W. A. Trifonov (Ed.), Ancient cultures near Kuban (on materials of archaeological works in zones of land improvement of Krasnodar territory) (pp. 92-166). Leningrad: Science.

Van Gerven, D. P. (1982). The contribution of time and local geography to craniofacial variation in Nubia's Batn el Hajar. American Journal of Physical Anthropology, 59, 307-316.

Wiik, K. (2003). The most ancient language to Europe?. Retrieved from http://www.lib.helsinki.fi/bff/399/wiik.html

Yusupov, R. M. (1989). Population anthropology Srubnaja cultures Southern Uralja. Materials on an epoch of bronze and early iron Southern Uralja and the Bottom Volga region, (pp. 34-41). Ufa.

Zubova, A. V. (2008). Anthropological structure of the population of Western Siberia during epoch of the developed and late bronze. Diss. PhD. Novosibirsk.

Zubova, A. V. (2010). Population Pit Grave cultural-historical generality in light odontologic data. Bulletin of archeology, anthropology and ethnography, 2(13), 85-95. 